\title{
HAPA-B 点滴静注の基礎的・臨床的検討
}

HAPA-B 点滴静注研究会

$$
\begin{aligned}
& \text { 国立霞ケ浦病院 } \\
& \text { 勝 正 孝*,** } \\
& \text { 東京慈恵会医科大学第 } 2 \text { 内科 } \\
& \text { 斎藤篤 } *, * * \\
& \text { 神奈川県立長浜病院呼吸器科 } \\
& \text { 小田切 繁 樹** } \\
& \text { 東京大学医学部泌尿器科 } \\
& \text { 岸洋 一** } \\
& \text { 北海道大学医療技術短期大学部 } \\
& \text { 斎藤玲 } \\
& \text { 札幌鉄道病院内科 } \\
& \text { 中山- 朗 } \\
& \text { 弘前大学医学部第 } 3 \text { 内科 } \\
& \text { 武 部 和 夫 } \\
& \text { 北秋中央病院内科 }
\end{aligned}
$$

田村 豊一遠藤 勝実 米田 政志

井戸 康夫

国立霞ケ浦病院内科

佐藤 実 山縣 元 奥井 津二 国立療養所東埼玉病院内科

$$
\text { 青 柳 昭 雄 }
$$

東京都済生会中央病院内科

北原 光夫高橋 幸 則

慶応義熟大学医学部内科

$$
\text { 外山 圭助 木 崎 昌 弘 }
$$

$$
\text { 清 水 喜八郎 }
$$$$
\text { 杏林大学第 } 1 \text { 内科 }
$$

小林宏行押谷浩吉田雅彦 東京慈恵会医科大学

$$
\text { 上田 泰 }
$$

東京都老人医療センタ一感染症科

稲 松 孝思

東京電力病院内科

船津雄三東冬彦

別刷請求先：（テ105）東京都港区西新橋 3-25-8 東京慈恵会医科大学第 2 内科

斎藤篤
川崎市立川崎病院内科

小林芳夫藤森一平 神奈川県衛生看護専門学校附属病院内科

$$
\text { 松本文夫 }
$$

神奈川県立長浜病院呼吸器科

松村 正典 鈴木 周男 室橋 光宇

鈴木 尚子吉池 保博 木内 充世

福田勉

富山県立中央病院内科

大 山 馨

関西医科大学第 1 内科

岡本 緩子 米津 精文 安永幸二郎 関西医科大学附属洛西ニュータウン病院内科

$$
\text { 上田良弘大久保滉 }
$$
奈良県立医科大学第 2 内科

澤木 政好 三笠 桂一 三上理一郎 川崎医科大学呼吸器内科

副島 林造 川根 博司 二木 芳人 安達 倫文岸本 寿男 角優 九州大学医学部第 1 内科, 医療技術短期大学部 澤江 義郎岡田 薰 熊谷 幸雄 長崎大学医学部第 2 内科

原耕平 斎藤 厚 山口 恵三 鈴山 洋司重野 芳輝河野茂 国立嬉野病院内科 木 谷 崇 和 五島中央病院内科

石崎驍道津安正 長崎大学熱帯医学研究所内科

松本 慶蔵 吉田 俊昭 大石和德 札幌医科大学泌尿器科

田仲 紀明 水戸部勝幸 熊本 悦明 獨協医科大学泌尿器科

村橋勲高崎悦司 東京大学医学部泌尿器科

富永登志新島端夫 東京共済病院泌尿器科 斉藤 功 
社会保険埼玉中央病院泌尿器科

$$
\text { 石 井 泰 憲 }
$$

東京慈恵会医科大学泌尿器科

町田豊平 小野寺昭一清田浩 国立大藏病院泌尿器科

斉 藤 賢 一

平塚市民病院泌尿器科

鈴木恵三 高 梨 勝 男

岐阜大学医学部泌尿器科

竹内 敏視 坂 義人 西浦常雄

神戸大学医学部泌尿器科 $(* * *$ 現国立神戸病院)

石神 襄次 ${ }^{* * *}$ 藤井 明 守殿 貞夫

兵庫県立加古川病院泌尿器科

大島秀夫
赤穂市民病院泌尿器科

中 野 康 治

岡山大学医学部泌尿器科

大森 弘之公文 裕巳 那須 良次 岡山赤十字病院泌尿器科

近藤 淳 近藤 捷嘉 岡山市民病院泌尿器科

難 波 克一

岡山中央病院泌尿器科

金重 哲 三

九州大学医学部泌尿器科

加治 慎一松本 哲朗 熊澤 浄一

\section{*: 世話人, ${ }^{* *}$ : 執筆者}

(昭和61年 6 月 10 日受付)

（昭和61年 7 月 15 日受理）

\section{Key words : HAPA-B, Intravenous drip infusion, Fundamental and clinical investigation}

\section{要旨}

新しいアミノグリコシド系抗生剂 HAPA-B の点滴静注投与に怙ける有効性拈よび安全性について基 礎的・臨床的検討を行った。

内科領域, 泌尿器科領域に拈ける諸感染症を対象とした. HAPA-B は原則として 1 回 $200 \mathrm{mg}$ を 1 日 2 回， 1 時間を中心として0.5時間から 2 時間かけて点滴静注し，以下の成績を得た.

1) HAPA-B 200mg, 1 時間点滴における血中濃度のピークは点滴終了時にあり,ピーク值の平均濃度

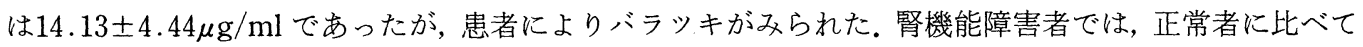
HAPA-B の排泄が遅れ，血中濃度の遷延する傾向がみられた。

2) 内科領域に打ける臨床効果は呼吸器感染症 61 例中 43 例 (70.5\%), 尿路感染症 6 例, 敗血症 4 例, その他の疾患 3 例ではいずれも全例著効ないしは有効で，全体では $75.7 \%(56 / 74)$ の有効率であった。 細菌学的効果は $62.5 \%$ の菌消失率であった。

3）泌尿器科領域に打ける臨床効果はUTI 薬効評価基準による判定では54.9\% (50/91), 主治医判定 では $61.2 \%(60 / 98)$ の有効率であった。菌消失率は $68.3 \%$ であった。

4）副作用の発現例は182例中食欲不振 1 例, 発熱 1 例, 皮疹 1 例の計 3 例 (1.6\%), 臨床検査値異常 の発現例は 9 例で，その多くはトランスアミナーゼの一過性の上昇であった。これらの副作用・臨床検 查值異常は, いずれも軽度で, 重篤なものはみられなかった。

5）以上の結果より，HAPA-B を点滴静注投与した際の有効性, 安全性は筋注投与時のそれと注济同 等と考号られ，点滴静注は有用な投与方法と考兄られた。

\section{緒言}

アミノグリコシド系抗生剂（以下 AGs 剂と略 記）はグラム陽性菌怙よびグラム陰性菌に対して 幅広い抗菌作用を示し，特に緑膿菌をはじめとす
るグラム陰性桿菌による難治の呼吸器感染症, 尿 路感染症には $\beta$-ラクタム系抗生剂々同様に重要 な位置を占めている。

HAPA-Bは新しいAGs 剂の一つで, 
Fig. 1 Chemical structure of HAPA-B

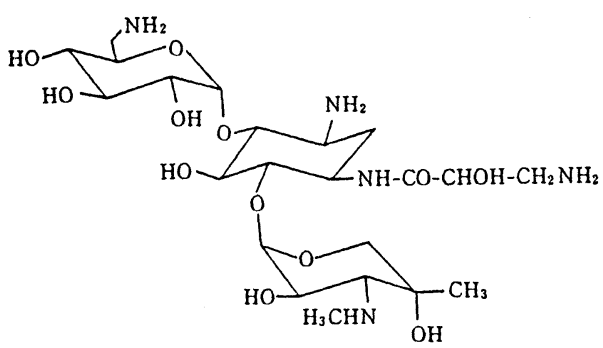

Gentamicin B の 1 位アミノ基が hydroxyaminopropionyl 化された Gentamicin B 誘導体 ${ }^{1)}$ で，そ の構造式は Fig. 1 に示すと拈りである.HAPA$\mathrm{B}$ はグラム陽性菌やグラム陰性菌に対し幅広い抗 菌力を有し， $\operatorname{AAC}\left(6^{\prime}\right)-4$ を除く種々の $\mathrm{AGs}$ 剂不 活化酵素に対して安定で耐性菌が少ないAGs 郕

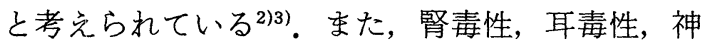
経一筋伝垟抑制作用は Gentamicin（以下 GM と略 記)は勿論のこと, Amikacin(以下 AMK と略記) より低いことが報告されている2). 本剤に関して は，筋注投与に打汀る基礎的，臨床的研究が現在 までに数多く実施され，第31回日本化学療法学会 東日本支部総会に招いて総合的に検討評価され た2)。その結果，内科領域に打いては67.9\%(190/ 280 ), 泌尿器科領域に招いてはUTI 薬効評価基準 による判定で57.0\%(159/279)，主治医判定で $59.9 \%(208 / 347)$ の有効率であり，副作用につい ては0.9\%(7/745) の発現率であった。

AGs 剂は腎毒性, 耳毒性, 神経一筋伝達抑制作用 による呼吸抑制作用などが知られて打り，をた薬 剂の有効量と中毒量の幅が狭いために使用しにく い薬剂とされ，従来主として筋注で投与されてき た。

一方，筋注時の疼痛，出血傾向のある患者およ び小児科領域における大腿四頭筋障害の問題，ま た輸液中ですでに血管が確保されている患者では 筋注時の苦痛軽減を目的として，点滴静注は極め て有用と考えられる。さらに点滴静注は近年, AGs 剂の血中濃度モニタリングの改良 ${ }^{4)}$, 毒性の軽減 などで，その使用法が増加する傾向にある5).

本剂に関しては，点滴静注に打ける臨床第一相 試験が実施されて敃り，本剂は 1 時間点滴静注に
おいて筋注とほぼ同様の体内動態を示し，0.5時間 から 2 時間点滴静注に执いて忍容性に問題のない ことが確認されだ).

今回，我々は点滴静注に打ける HAPA-B の有 効性, 安全性を検討する目的で, 内科領域执よび 泌尿器科領域感染症を対象として基礎的・臨床的 研究を行ったので，以下にその成績を報告する。

\section{I. 方 法}

\section{1. 体液内濃度測定}

1）血中濃度

HAPA-B $200 \mathrm{mg}$ を年齢 $42 \sim 74$ 歳（平均 $66.0 \pm$ 11.1歳)の臨床検討患者 7 例に，0.5時間かけて点 滴静注し，初回投与時に扮ける HAPA-B の血中 濃度の推移を検討した。 そのらちの 1 例は C cr 84 $\mathrm{ml} / \mathrm{min}$.の腎機能正常者であった。

同様に, HAPA-B 200mg を年齢45 85歳(平均 $69.0 \pm 10.6$ 歳）の臨床検討患者 23 例，年齢18～87 歳（平均 $61.7 \pm 21.7$ 歳）の臨床検討患者 15 例に, それぞれ 1 時間かけて点滴静注し，初回投与時抒 よび連続投与時に括ける, HAPA-B の血中濃度推 移を検討した。初回投与23例のうち, Ccr が明らか なのは Table 1 に示す 9 例であった。

採血は，点滴静注終了時㐨上び次回点滴静注直 前の 2 ポイントの他, 可能な限り経時的に行った。

2）腎機能障害者に対する血中および尿中濃度

腎機能障害患者（Ccr 30.6 62.6ml/min.）6例 にHAPA-B 200mg を 1 回 1 時間をかけて点滴静 注したのち経時的に採血および採尿し，血中和よ び尿中の HAPA-B 濃度を測定した。

また，腎機能の正常な患者 (Ccr 81.7 95.4ml/ min.) 3 例に対しても同様に血中，尿中の HAPA-

Table 1 Background of 9 patients with Ccr value

\begin{tabular}{ccccc}
\hline No. & Age & Sex & Body weight $(\mathrm{kg})$ & Ccr $(\mathrm{ml} / \mathrm{min})$. \\
\hline 1 & 77 & Male & 52 & 95.4 \\
2 & 73 & Male & 54 & 82.2 \\
3 & 71 & Male & & 81.7 \\
4 & 61 & Male & 48 & 69.7 \\
5 & 64 & Male & 49 & 50.7 \\
6 & 85 & Female & 31 & 49.7 \\
7 & 74 & Male & 49 & 40.8 \\
8 & 77 & Male & 47 & 33.9 \\
9 & 49 & Male & 50 & 30.6 \\
\hline
\end{tabular}


B 濃度を測定し, HAPA-Bに拈ける血中および尿 中濃度の推移と Ccr の関係を検討した。

3）血中，尿中拉よび喀痰中濃度

慢性気管支炎患者 1 例に HAPA-B 200mg 1 時間かけて点滴静注投与し, 経時的に採血, 採尿, 蓄痰して HAPA-B 濃度を測定した。

\section{4）方法}

HAPA-B 濃度はBacillus subtilis ATCC 6633 株を検定菌とする二層 Agar well 法で測定した。 培地には基層に Agar 1.5\%, $\mathrm{NaCl} 0.4 \%$ ，種層 に普通寒天培地（栄研）を使用した。標準曲線の 作製拉よび検体の希釈にはヒト血漿，尿あるいは

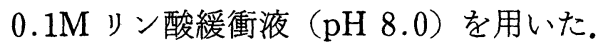
喀痰は $1 \mathrm{~g}$ 当り Trypsin $40 \mathrm{mg}$ を加光, $37^{\circ} \mathrm{C}, 60$
分間処理して測定に供した。

\section{2. 臨床的検討}

1) 対象

臨床評価の検討は Table 2,3 のごとく, 内科領 域19施設, 泌尿器科領域 9 施設掞よびそれらの関 連施設において1985年 2 月から1985年11月にわ たって実施した。内科領域においては呼吸器感染 症, 尿路感染症, 敗血症などを, 泌尿器科領域に 扣いては複雑性尿路感染症を主な対象疾患とし た。対象患者は原則として成人の入院患者とし， 下記患者は対象より除外した。

（1）極めて重篤な患者

（2）腎あるいは肝機能障害を有する患者

（3）AGs 剂あるいはバシトラシンに過敏症の

Table 2 Collaborating Clinics

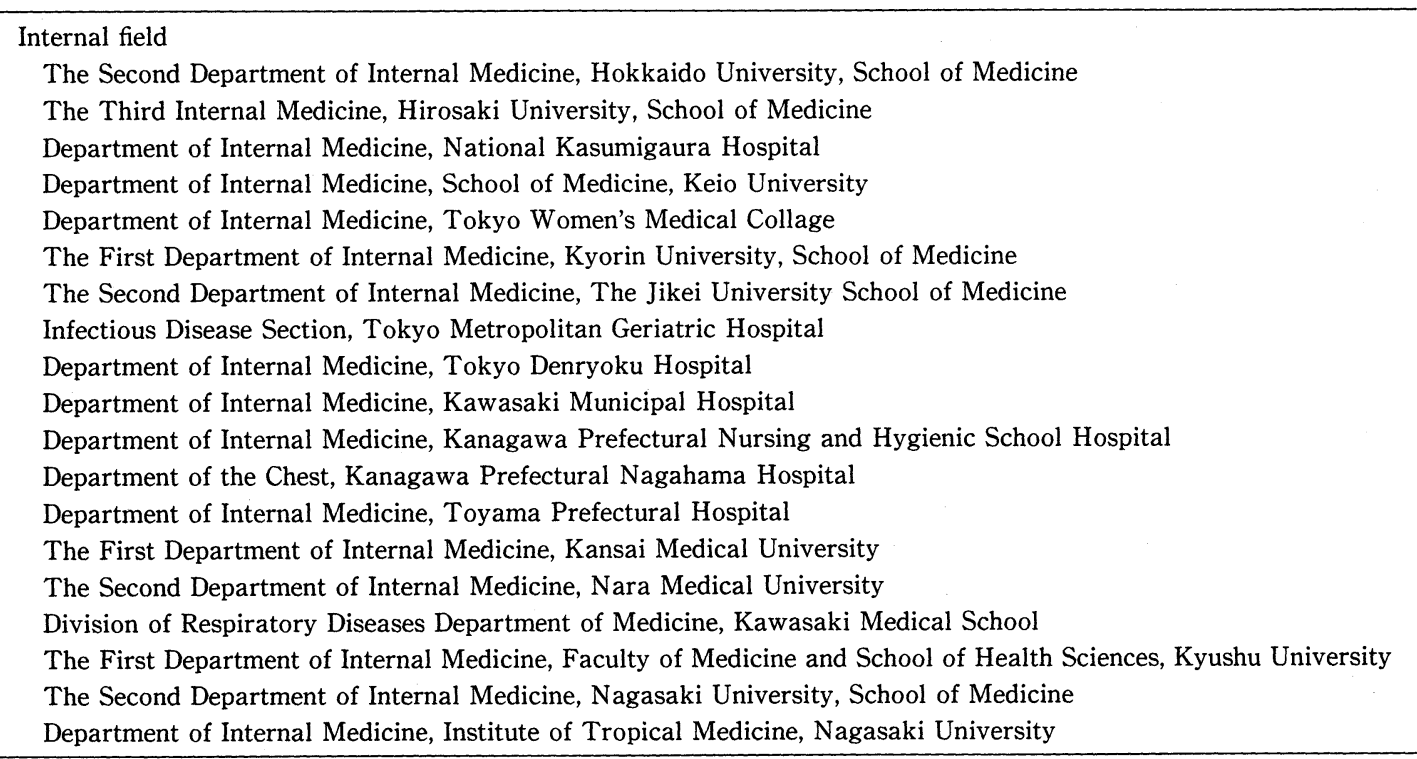

Table 3 Collaborating Clinics

Urological field
Department of Urology, Sapporo Medical College
Department of Urology, Dokkyo University School of Medicine
Department of Urology, Faculty of Medicine, University of Tokyo
Department of Urology, The Jikei University School of Medicine
Department of Urology, Hiratsuka Municipal Hospital
Department of Urology, Gifu University School of Medicine
Department of Urology, Kobe University School of Medicine
Department of Urology, Okayama University, Medical School
Department of Urology, Faculty of Medicine, Kyushu University


既往のある患者

（4）本人またはその血族がストレプトマイシン 難聴をたはその他の難聴である患者

（5）妊婦および授乳中の患者

（6）その他主治医が本剂の投与を不適当と判断 した患者

な拈，臨床検討の実施にあたっては，各施設の 実情に合わせた方法で患者の承諾を得ることとし た.

\section{2）投与方法}

原則として 1 回 $200 \mathrm{mg}$ を生理食塩液，電解質溶 液，糖液など100〜 $500 \mathrm{ml}$ に溶解して 1 日 2 回，1 時間を中心として0.5時間から 2 時間かけて点滴 静注することとした。投与期間は原則として14日 間を限度とし，病態に応じて主治医が決定した。

3）効果判定

臨床効果の判定は, 内科領域の呼吸器感染症で は発熱，咳嗽，喀痰（量・性状），呼吸困難，胸部 ラ音などの自・他覚所見のほか，胸部レ線像，血 沈，CRP，白血球数などの検査成績，尿路感染症 では頻尿, 残尿感, 腰部吒打痛などのほか, CRP, 白血球数，尿所見などの検査成績，その他の内科 領域の感染症では発熱などの自覚症状のほか，血 沈，CRP，白血球数なぞの検査成績と，それぞれ の細菌学的効果を勘案して総合的に主治医が行っ た。細菌学的効果は消失, 減少, 不変, 菌交代, 不明 に分類した。泌尿器科領域では, UTI 薬効評価基 準7)による判定と発熱，頻尿，排尿痛などの自覚症 状扣よび CRP，血沈，白血球数，尿所見などの検 査成績を加味した主治医判定の双方で判定した。 主治医判定は内科領域, 泌尿器科領域ともに著効, 有効, やや有効, 無効の 4 段階で判定し, 有効率 は著効例と有効例を含め，効果判定不明例を除い た全症例に対する割合で示した。

4）副作用抒よび臨床検查值の異常

副作用については発疹などのアレルギー症状, 下痢などの消化器症状, 浮腫などの循環器症状お よび聴力などについて注意深く観察した。副作用 と考兄られる症状の発現時には, 本剂之の関連性, その症状, 程度, 出現の時期, 本剂継続投与の可否, 処置,その後の経過などを詳細に記録した。
臨症検査值については本剂使用前後の末梢血, 血清生化学，尿所見などを検索した，異常变動が みられた際には，その後の経過抒よび異常変動の 推定原因について主治医のコメントを記録した。

\section{II. 成 績}

\section{1. 体液内濃度測定}

1）血中濃度

Fig. 2 Serum and plasma concentration of HAPA-B after intravenous drip infusion of $200 \mathrm{mg}$. (Initial administration, $\mathrm{n}: 7$ )

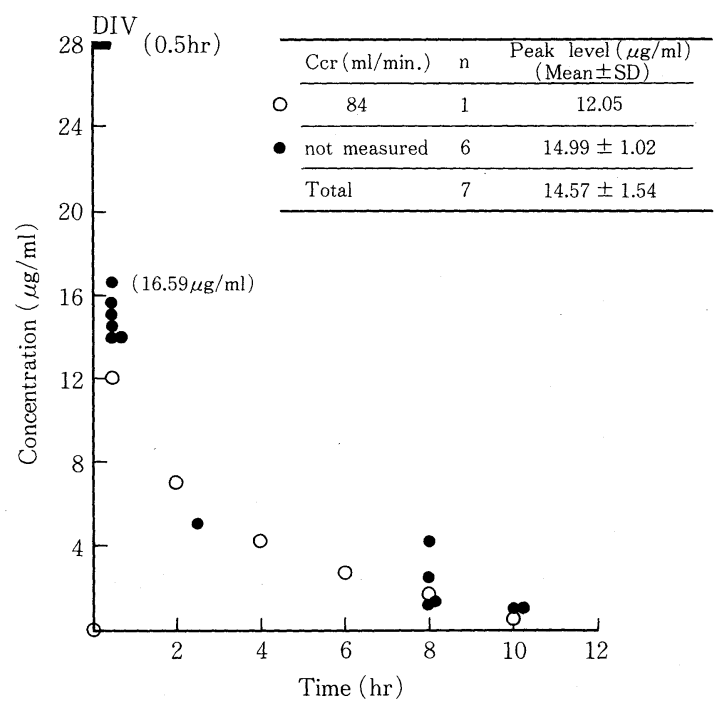

Fig. 3 Serum and plasma concentration of HAPA-B after intravenous drip infusion of $200 \mathrm{mg}$. (Initial administration, $\mathrm{n}: 23$ )

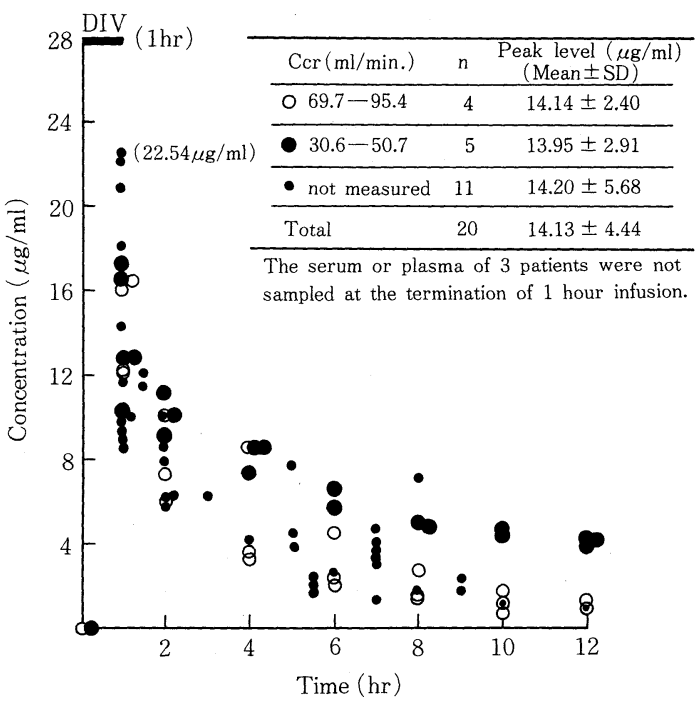


HAPA-B 200mg 7 例の患者に対し，0.5時間 かけて点滴静注したときの初回投与時の血中濃度 をFig. 2 に示した。血中濃度のピークは0.5時間 にあり，その值は $12.05 \sim 16.59 \mu \mathrm{g} / \mathrm{ml}$ (平均 14.57 $\pm 1.54 \mu \mathrm{g} / \mathrm{ml})$ で, 以後は比較的すみやかに低下し た.

HAPA-B 200mg 23例の患者に 1 時間点滴静 注したときの初回投与時の血中濃度推移を Fig.

Fig. 4 Serum and plasma concentration of HAPA-B after intravenous drip infusion of 200mg. (3-14 times administration, $n: 15$ )

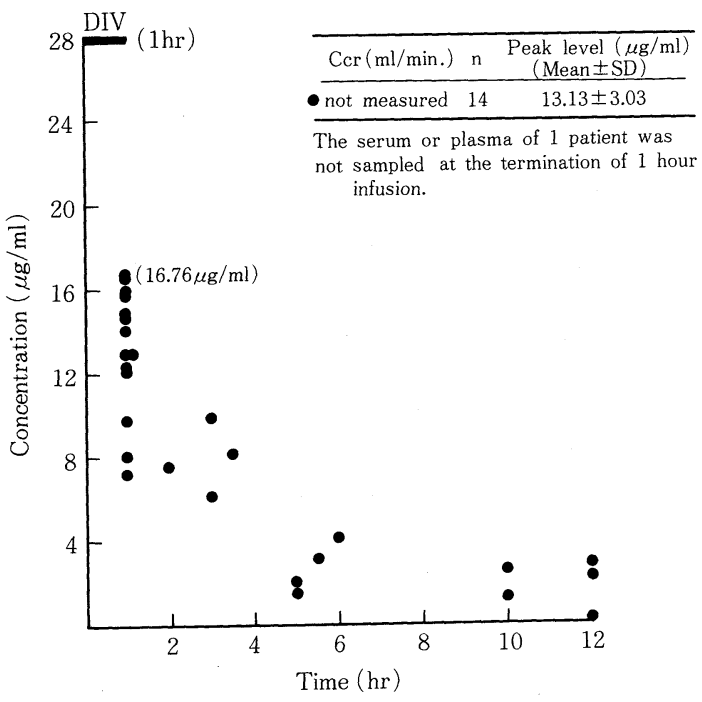

Fig. 5 Plasma concentration of HAPA-B after intravenous drip infusion of $200 \mathrm{mg}$ in patients with impaired renal function.

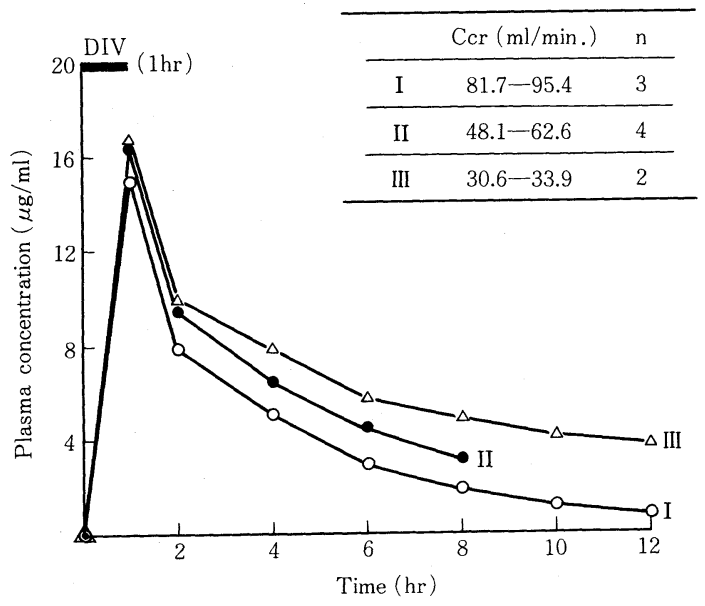

3 に, また同様に15例の患者での連投中の血中濃 度を Fig. 4 に示した. 血中濃度のピークはいずれ

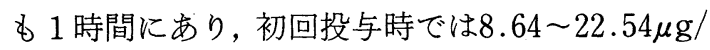
$\mathrm{ml}$ (平均 $14.13 \pm 4.44 \mu \mathrm{g} / \mathrm{ml}$ ), 連投中では7.18 $16.76 \mu \mathrm{g} / \mathrm{ml}$ (平均 $13.13 \pm 3.03 \mu \mathrm{g} / \mathrm{ml}$ ) で, 0.5 時 間点滴静注同様に以後は比較的すみやかに低下し た。また, Fig. 3 に示したように Ccr の明らかな 患者 9 例では, $\operatorname{Ccr} 50.7 \mathrm{ml} / \mathrm{min}$. 以下の患者 $(\mathrm{n}=$ 5) と C cr $69.7 \mathrm{ml} / \mathrm{min}$. 以上の患者 $(\mathrm{n}=4)$ を比 較すると,ピーク值の平均濃度はそれぞれ13.95 士 $2.91 \mu \mathrm{g} / \mathrm{ml}, 14.14 \pm 2.40 \mu \mathrm{g} / \mathrm{ml}$ でほぼ同等で あったが，Ccr $50.7 \mathrm{ml} / \mathrm{min}$. 以下の患者では血中 濃度の持続遷延する傾向がみられた。

2）腎機能障害者に対する血中および尿中濃度

HAPA-B 200mg を腎機能正常者 3 例抢よび障 害者 6 例に 1 時間かけて点滴静注したときの血中 濃度推移を Fig. 5 に示した。 Ccr 81.7〜 95.4ml/ min. の腎機能正常群に扔ける血中濃度は点滴終 了時に平均ピーク值 $14.88 \mu \mathrm{g} / \mathrm{ml}$ を示し, 以後は 比較的すみやかに低下した. Ccr 48.1 62.6ml/ min. の軽度障害群 $(\mathrm{n}=4), \operatorname{Ccr} 30.6 \sim 33.9 \mathrm{ml} /$ $\min$. の中等度障害群 $(n=2)$ では腎機能正常群と 同様に点滴終了時にピーク値を示し，その平均濃 度は $16.33 \mu \mathrm{g} / \mathrm{ml}$ および $16.93 \mu \mathrm{g} / \mathrm{ml}$ であった。以

Fig. 6 Urinary excretion of HAPA-B after intravenous drip infusion of $200 \mathrm{mg}$ in patients with impaired renal function

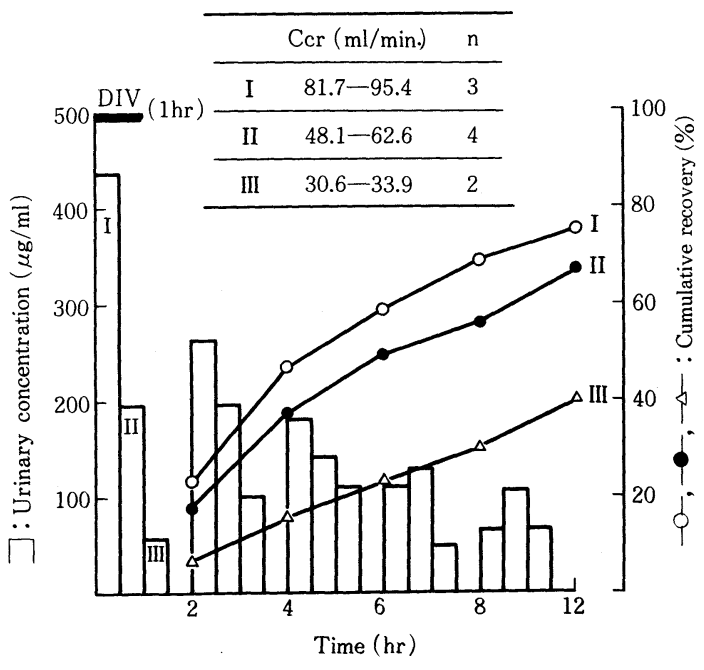


後は両群ともに漸減したが，腎機能の低下に従い 血中濃度の持続遷延する傾向が認められた。

同様に, HAPA-B 200mgを 1 時間かけて点滴 静注したときの尿中濃度推移打よび尿中回収率を Fig. 6 に示した。腎機能正常群では12時間むでに

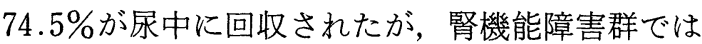
回収率の低下傾向がみられ，12時間までに軽度障 害群では $66.6 \%$, 中等度障害群では $38.4 \%$ であっ た.

また，各症例の血中濃度から最小二乗法により $\beta$ 相での血中半減期 $T_{1 / 2}(\beta)$ を求め, Fig. 7 K $\operatorname{Ccr}$ と $T_{1 / 2}(\beta)$ の関係を示した. C cr の減少する に従い， $T_{1 / 2}(\beta)$ の延長する傾向が認められた。

3）血中，尿中扝よび喀痰中濃度

慢性気管支炎患者 (64歳, 女性, 33kg) 飞 HAPAB 200mgを 1 時間かけて点滴静注したときの HAPA-B の血中，尿中，喀痰中濃度和よび尿中回 收率の経時的変化は Fig. 8 に示すと拈りである。 血中濃度のピークは点滴終了時にあり $(18.12 \mu \mathrm{g} /$ $\mathrm{ml})$ ，以後漸減した。また， 8 時間までに $71.7 \%$ ま 尿中に回収された。

一方，喀痰中濃度のピークは $1 \sim 3$ 時間で 1.03 $\mu \mathrm{g} / \mathrm{g}$ であり, 最高喀痰中濃度の血中ピーク值に 対する割合は $5.7 \%$ であった。

\section{2. 郒床的検討}

1) 内科領域

内科領域に扔いて HAPA-Bが投与された総症

Fig. 7 Correlation between $\mathrm{Ccr}$ and $\mathrm{T}_{1 / 2}(\beta)$

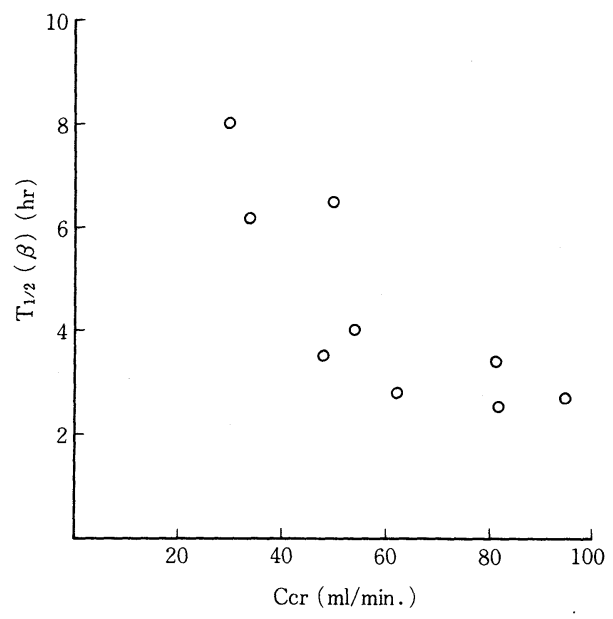

Fig. 8 Plasma, urinary and sputum concentration of HAPA-B after intravenous drip infusion of $200 \mathrm{mg}$.

Male, 64 y.o., 33kg, Chronic bronchitis

1) Plasma concentration

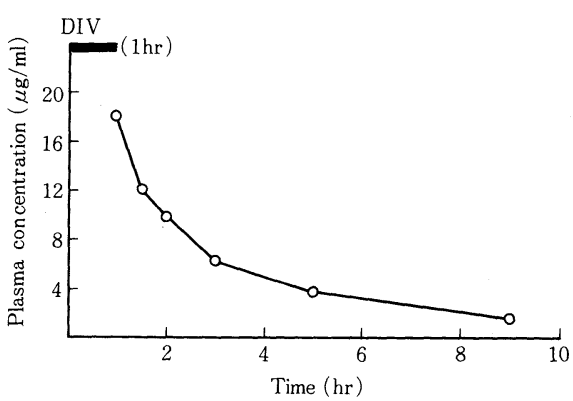

2) Urinary concentration
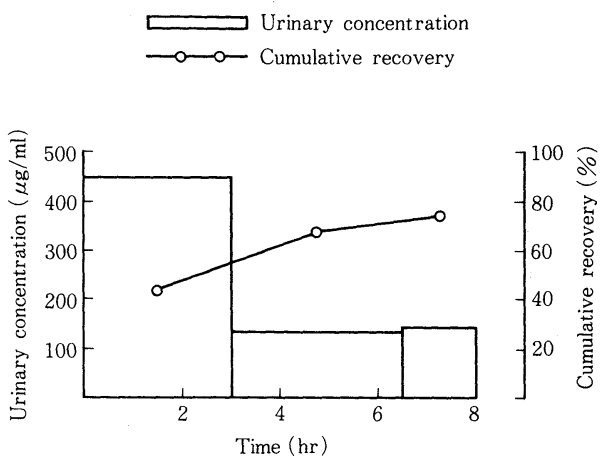

3) Sputum concentration

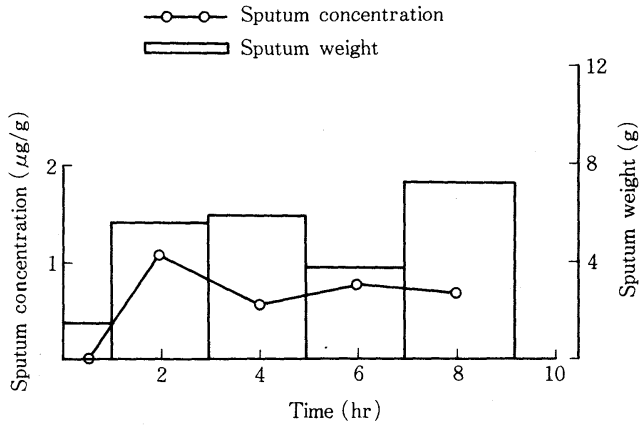

例数は81例であった，そのらち，感染症状が不明 確のため判定不能とした 3 例, 対象外疾患 2 例, 他の抗生剂を併用した 1 例，副作用で中止した 1 例の計 7 例を除外をたは脱落例とし，74例に対し て有効性の解析を行った。疾患群の内訳は呼吸器 感染症61例, 尿路感染症 6 例, 敗血症 4 例, その 他 3 例であった（Table 4). 
Table 4 Case distribution

\begin{tabular}{lccc}
\hline Disease group & $\begin{array}{c}\text { Total number of } \\
\text { patients }\end{array}$ & $\begin{array}{c}\text { No. of patients } \\
\text { excluded from } \\
\text { analysis }\end{array}$ & $\begin{array}{c}\text { No. of patients } \\
\text { included in } \\
\text { analysis }\end{array}$ \\
\hline Sepsis & 5 & 1 & 4 \\
Respiratory tract infection & 65 & 4 & 61 \\
Urinary tract infection & 7 & 1 & 6 \\
Other infection & 4 & 1 & 3 \\
\hline \multicolumn{1}{c}{ Total } & 81 & 7 & 74 \\
\hline \multicolumn{1}{c}{ Reasons for exclusions or drop-outs } & Symptoms of infection unclear & 3 \\
& Combined administration with other antibiotics & 1 \\
& Diseases out of the object & 2 \\
& Discontinued treatment due to side effect & 1
\end{tabular}

（1）患者背景因子

a ) 性別，年齢（Table 5)

74 例の内訳は男性50例, 女性24例で, 男性 2 対 女性 1 の比率であった。年齢は14 86歳（平均 $56.4 \pm 19.2$ 歳)で, 60 歳以上の症例が全体の約 $50 \%$ を占めた。

b) 点滴時間と溶解液量（Table 6)

Table 5 Background of patients (Age, Sex)

\begin{tabular}{|c|c|c|c|c|}
\hline \multirow{2}{*}{ Age } & \multicolumn{2}{|c|}{ Sex } & \multirow{2}{*}{ Total } & \multirow{2}{*}{ (Rate \%) } \\
\hline & Male & Female & & \\
\hline$\sim 19$ & 2 & 2 & 4 & $(5.4)$ \\
\hline $20 \sim 29$ & 1 & 3 & 4 & $(5.4)$ \\
\hline $30 \sim 39$ & 4 & 1 & 5 & $(6.8)$ \\
\hline $40 \sim 49$ & 9 & 4 & 13 & (17.6) \\
\hline $50 \sim 59$ & 8 & 5 & 13 & (17.6) \\
\hline $60 \sim 69$ & 10 & 4 & 14 & $(18.9)$ \\
\hline $70 \sim 79$ & 10 & 2 & 12 & $(16.2)\}(47.3)$ \\
\hline $80 \sim$ & 6 & 3 & 9 & $(12.2))$ \\
\hline $\begin{array}{c}\text { Total } \\
\text { (Rate \%) }\end{array}$ & $\begin{array}{l}50 \\
(67.6)\end{array}$ & $\begin{array}{l}24 \\
(32.4)\end{array}$ & $\begin{array}{c}74 \\
(100)\end{array}$ & $(100)$ \\
\hline
\end{tabular}

(14 86y.o.) (Mean \pm S.D. : $56.4 \pm 19.2$ y.o. $)$
点滴時間は 1 時間が全体の $90.5 \%$ をまた溶解 液量は 100 ～ $250 \mathrm{ml}$ が87.8\%を占めた. すなわち， 点滴時間 1 時間, 溶解液量 $100 \sim 250 \mathrm{ml}$ の症例がほ とんどであった。

c) 投与量, 投与日数 (Table 7)

1 日 $400 \mathrm{mg}$ を 2 回に分けて投与した症例が全 体の $97.3 \%$ 占めた。 その他では，わずかに 2 例 が 1 日 $600 \mathrm{mg}$ を 3 回に分割投与された。

投与日数は7〜14日間が最も多く,全体の $70.3 \%$

Table 6 Background of patients (Infusion time and volume)

\begin{tabular}{|c|c|c|c|c|c|c|c|}
\hline \multirow{2}{*}{$\underset{(\mathrm{hr})}{\text { Time }}$} & \multicolumn{5}{|c|}{ Volume (ml) } & \multirow{2}{*}{ Total } & \multirow{2}{*}{ (Rate \%) } \\
\hline & 100 & 200 & 250 & 300 & 500 & & \\
\hline 0.5 & 1 & & & & & 1 & $(1.4)$ \\
\hline 1.0 & 36 & 16 & 12 & 2 & 1 & 67 & $(90.5)$ \\
\hline 1.5 & & & & 3 & & 3 & $(4.1)$ \\
\hline 2.0 & & & & & 3 & 3 & $(4.1)$ \\
\hline Total & $\begin{array}{c}37 \\
(50.0)\end{array}$ & $\begin{array}{c}16 \\
(21.6)\end{array}$ & $\begin{array}{c}12 \\
(16.2)\end{array}$ & $\begin{array}{c}5 \\
(6.8)\end{array}$ & $\begin{array}{c}4 \\
(5.4)\end{array}$ & $\begin{array}{c}74 \\
(100)\end{array}$ & (100) \\
\hline \multirow[t]{2}{*}{ (Rate \%) } & \multicolumn{3}{|c|}{ (37.8) } & & & & \\
\hline & \multicolumn{3}{|c|}{$(87.8)$} & & & & \\
\hline
\end{tabular}

Table 7 Background of patients (Dose, Duration)

\begin{tabular}{|c|c|c|c|c|c|c|c|c|c|c|c|c|c|c|c|c|}
\hline \multirow{2}{*}{$\begin{array}{c}\text { Dose } \\
\begin{array}{c}\text { mg } \times \text { times/ } \\
\text { day })\end{array}\end{array}$} & \multicolumn{14}{|c|}{ Duration (days) } & \multirow{2}{*}{ Total } & \multirow{2}{*}{ (Rate \%) } \\
\hline & $\sim 3$ & 4 & 5 & 6 & 7 & 8 & 9 & 10 & 11 & 12 & 13 & 14 & $15 \sim 21$ & $22 \sim$ & & \\
\hline $200 \times 2$ & 2 & 2 & 2 & 4 & 10 & 6 & 3 & 11 & & 4 & 2 & 14 & 11 & 1 & 72 & $(97.3)$ \\
\hline $200 \times 3$ & & & & & & 1 & & 1 & & & & & & & 2 & $(2.7)$ \\
\hline \multirow{2}{*}{$\begin{array}{c}\text { Total } \\
\text { (Rate \%) }\end{array}$} & $\begin{array}{c}2 \\
(2.7)\end{array}$ & $\begin{array}{c}2 \\
(2.7)\end{array}$ & $\begin{array}{c}2 \\
(2.7)\end{array}$ & $\begin{array}{c}4 \\
(5.4)\end{array}$ & $\begin{array}{c}10 \\
(13.5)\end{array}$ & $\begin{array}{c}7 \\
(9.5)\end{array}$ & $\begin{array}{c}3 \\
(4.1)\end{array}$ & $\begin{array}{c}12 \\
(16.2)\end{array}$ & & $\begin{array}{c}4 \\
(5.4)\end{array}$ & $\begin{array}{c}2 \\
(2.7)\end{array}$ & $\begin{array}{c}14 \\
(18.9)\end{array}$ & \multirow[t]{2}{*}{$\begin{array}{c}11 \\
(14.9)\end{array}$} & \multirow[t]{2}{*}{$\begin{array}{c}1 \\
(1.4)\end{array}$} & $\begin{array}{c}74 \\
(100)\end{array}$ & \multirow[t]{2}{*}{$(100)$} \\
\hline & \multicolumn{13}{|c|}{$(70.3)$} & & & \\
\hline
\end{tabular}


を占めた. 15 日間以上の長期間投与症例は 12 例に認 められ, 最高投与日数は 35 日間, 総投与量は $14.0 \mathrm{~g}$ であった。

d) 基礎疾患・合併症, 感染症の重症度 (Table 8)

基礎疾患・合併症を有する症例が51例（68.9\%） 含まれていた。をた，感染症の重症度を主治医判 定で軽症・中等症・重症の 3 段階に分類すると, 軽症16例 (21.6\%), 中等症50例 (67.6\%), 重症 8 例（10.8\%）であった，全体として基礎疾患を 有し，中等症以上の症例が多く, AGs 剂としての HAPA-B の臨床的評価にた壳らる症例構成と考 觉られた。

Table 8 Background of patients (Severity, Underlying diseases and complications)

\begin{tabular}{|c|c|c|c|c|c|}
\hline \multirow{2}{*}{$\begin{array}{l}\text { Underlying diseases } \\
\text { and complications }\end{array}$} & \multicolumn{3}{|c|}{ Severity } & \multirow{2}{*}{ Total } & \multirow{2}{*}{ (Rate \%) } \\
\hline & Mild & Moderate & Severe & & \\
\hline Yes & 8 & 35 & 8 & 51 & $(68.9)$ \\
\hline No & 8 & 15 & 0 & 23 & $(31.1)$ \\
\hline $\begin{array}{c}\text { Total } \\
\text { (Rate \%) }\end{array}$ & $\begin{array}{c}16 \\
(21.6)\end{array}$ & $\begin{array}{c}50 \\
(67.6)\end{array}$ & $\begin{array}{c}8 \\
(10.8)\end{array}$ & $\begin{array}{c}74 \\
(100)\end{array}$ & $(100)$ \\
\hline
\end{tabular}

(2) 臨床効果

全症例の臨床効果は74例中，著効 13 例，有効 43 例，やや有効 9 例，無効 9 例で，有効率 $75.7 \%$ の 成績であった。

a ) 疾患別臨床効果 (Table 9)

疾患群別の臨床効果は呼吸器感染症では70.5\% (43/61) の有効率であり，尿路感染症の 6 例，敗 血症の 4 例, その他の疾患の 3 例では全例が著効 ないし有効であった。

疾患別有効率は肺炎で $81.5 \%(22 / 27)$ の優れた 成績が得られた。一方，慢性気管支炎では $64.3 \%$ (9/14)，気管支拡張症では $50.0 \%(4 / 8) ，$ 気管支 喘息・肺線維症・陳旧性肺結核などに合併した感 染では75.0\%（3/4）の成績であった。

尿路感染症は少数例ではあったが，急性腎孟腎 炎に対して全例有効 (6/6)の優れた成績が得られ た.

b ) 分離菌別臨床効果 (Table 10)

起炎菌が分離された42例の分離菌別臨床効果 は, グラム陽性菌の単独感染10例では $80.0 \%$ 有 効率であり，そのらちS. aureus の分離された 5

Table 9 Clinical effects of HAPA-B classified by diagnosis

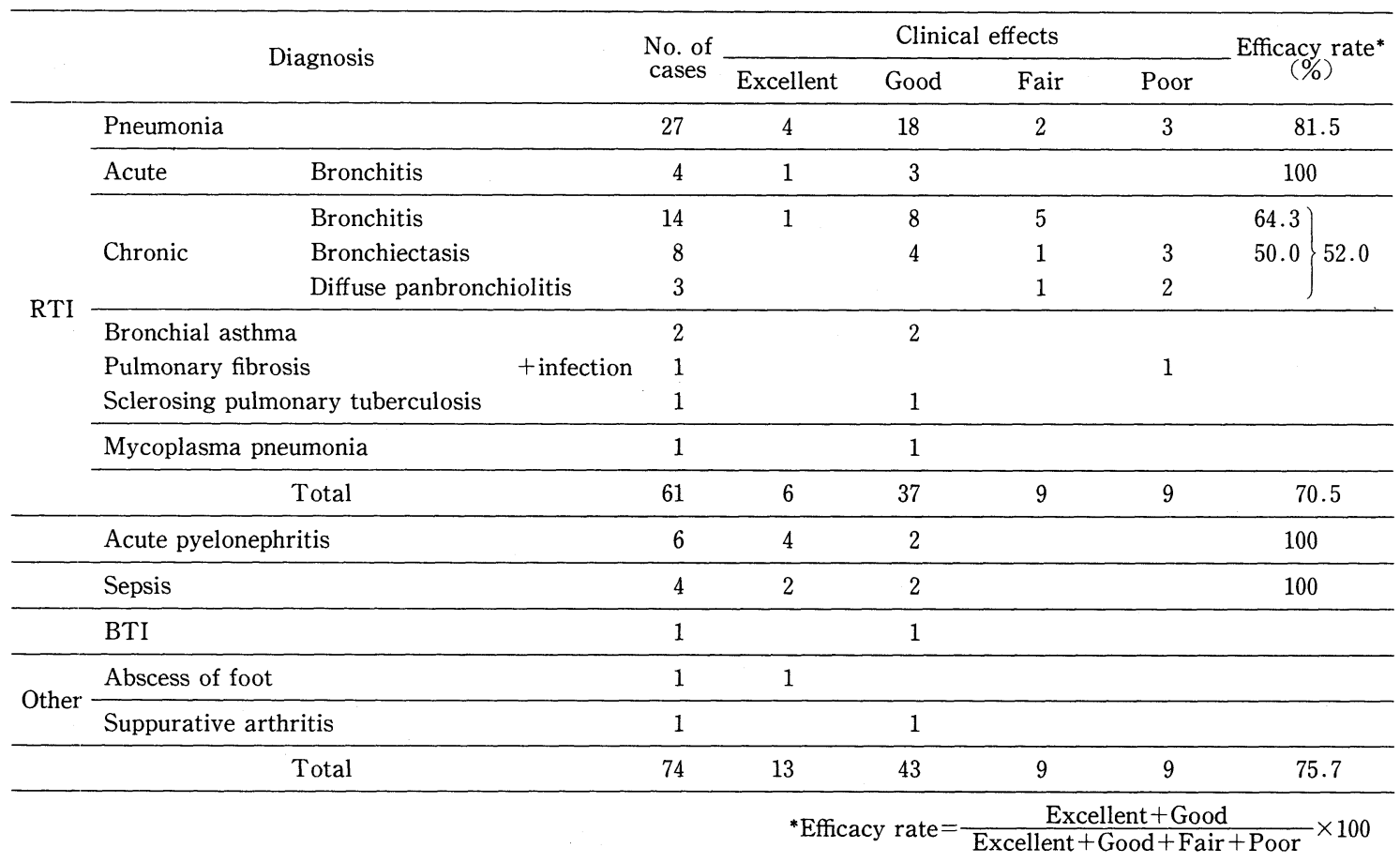


Table 10 Clinical effects of HAPA-B classified by causative organisms

\begin{tabular}{|c|c|c|c|c|c|c|c|}
\hline \multirow{2}{*}{\multicolumn{2}{|c|}{ Causative organisms }} & \multirow{2}{*}{ No. of cases } & \multicolumn{4}{|c|}{ Clinical effects } & \multirow{2}{*}{$\begin{array}{c}\text { Efficacy* } \\
\text { rate } \\
(\%)\end{array}$} \\
\hline & & & Excellent & Good & Fair & Poor & \\
\hline \multirow{4}{*}{ Gram postive } & S. aureus & 5 & 1 & 2 & 1 & 1 & 60.0 \\
\hline & E. faecalis & 2 & & 2 & & & \\
\hline & S. pneumoniae & 3 & & 3 & & & 100 \\
\hline & Subtotal & 10 & 1 & 7 & 1 & 1 & 80.0 \\
\hline \multirow{3}{*}{$\begin{array}{l}\text { Single } \\
\text { infection }\end{array}$} & E. coli & 7 & 4 & 3 & & & 100 \\
\hline & K. pneumoniae & 2 & & 2 & & & \\
\hline & H. influenzae & 9 & 1 & 4 & 4 & & 55.6 \\
\hline \multirow{6}{*}{ Gram negative } & P. aeruginosa & 6 & & 2 & 1 & 3 & 33.3 \\
\hline & A. calcoaceticus & 1 & & & & 1 & \\
\hline & $Y$. enterocolitica & 1 & 1 & & & & \\
\hline & B. catarrhalis & 1 & & 1 & & & \\
\hline & Subtotal & 27 & 6 & 12 & 5 & 4 & 66.7 \\
\hline & Total & 37 & 7 & 19 & 6 & 5 & 70.3 \\
\hline $\begin{array}{l}\text { Mixed } \\
\text { infection }\end{array}$ & Two species & 5 & & 4 & & 1 & 80.0 \\
\hline \multicolumn{2}{|c|}{ Total } & 42 & 7 & 23 & 6 & 6 & 71.4 \\
\hline
\end{tabular}

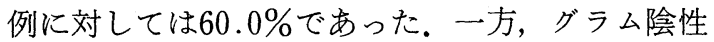
菌の単独感染27例では66.7\% (18/27) の有効率が 得られ, その内訳は E. coli $100 \%(7 / 7), H$. influenzae 55.6\% (5/9)であったが, P. aeruginosa に は33.3\% (2/6) の低い有効率であった。二菌種に
よる混合感染の 5 症例は $80.0 \%$ 有効率であっ た。

C ）基礎疾患 - 合併症有無別, 重症度別臨床効 果

基礎疾患・合併症有無別の臨症効果を Table 11

Table 11 Clinical effects of HAPA-B classified by presence of underlying diseases and complications

\begin{tabular}{|c|c|c|c|c|c|c|}
\hline \multirow{2}{*}{$\begin{array}{l}\text { Underlying diseases } \\
\text { and complications }\end{array}$} & \multirow{2}{*}{ No. of cases } & \multicolumn{4}{|c|}{ Clinical effects } & \multirow{2}{*}{ Efficacy rate $(\%)^{*}$} \\
\hline & & Excellent & Good & Fair & Poor & \\
\hline Yes & 51 & 8 & 25 & 9 & 9 & 64.7 \\
\hline No & 23 & 5 & 18 & & & 100 \\
\hline Total & 74 & 13 & 43 & 9 & 9 & 75.7 \\
\hline
\end{tabular}

Table 12 Clinical effects of HAPA-B classified by severity

\begin{tabular}{|c|c|c|c|c|c|c|}
\hline \multirow{2}{*}{ Severity } & \multirow{2}{*}{ No. of cases } & \multicolumn{4}{|c|}{ Clinical effects } & \multirow{2}{*}{ Efficacy rate $(\%)^{*}$} \\
\hline & & Excellent & Good & Fair & Poor & \\
\hline Mild & 16 & 3 & 11 & 1 & 1 & 87.5 \\
\hline Moderate & 50 & 8 & 28 & 7 & 7 & 72.0 \\
\hline Severe & 8 & 2 & 4 & 1 & 1 & 75.0 \\
\hline Total & 74 & 13 & 43 & 9 & 9 & 75.7 \\
\hline
\end{tabular}


に示した. 基礎疾患・合併症を有する群では $64.7 \%$

(33/51) と, 有しない群の $100 \%(23 / 23)$ に比し て低い有効率にとどまった。

感染症の重症度別臨床効果は Table 12 に示す と扮りである。軽症群の有効率は $87.5 \%(14 / 16)$
で最も優れ，中等症，重症群ではそれぞれ $72.0 \%$ (36/50)，75.0\%（6/8）の有効率であった。

（3）分離菌別細菌学的効果 (Table 13)

単独感染のらちグラム陽性菌の分離された10例

の細菌学的効果は $75.0 \%$ 除菌率で, そのらちS.

Table 13 Bacteriological effects of HAPA-B classified by causative organisms

\begin{tabular}{|c|c|c|c|c|c|c|c|c|}
\hline \multirow{2}{*}{\multicolumn{2}{|c|}{ Causative organisms }} & \multirow{2}{*}{$\begin{array}{l}\text { No. of } \\
\text { cases }\end{array}$} & \multicolumn{5}{|c|}{ Bacteriological effects } & \multirow{2}{*}{$\begin{array}{l}\text { Eradication* } \\
\text { rate }(\%)\end{array}$} \\
\hline & & & Eradicated & Decreased & Unchanged & Replaced & Unknown & \\
\hline \multirow{4}{*}{ Gram positive } & S. aureus & 5 & 2 & & 2 & & 1 & 50.0 \\
\hline & E. faecalis & 2 & & & & 1 & 1 & \\
\hline & S. pneumoniae & 3 & 3 & & & & & 100 \\
\hline & Subtotal & 10 & 5 & & 2 & 1 & 2 & 75.0 \\
\hline \multirow{3}{*}{$\begin{array}{l}\text { Single } \\
\text { infection }\end{array}$} & E. coli & 7 & 7 & & & & & 100 \\
\hline & K. pneumoniae & 2 & 2 & & & & & \\
\hline & H. influenzae & 9 & 5 & 1 & 3 & & & 55.6 \\
\hline \multirow[t]{6}{*}{ Gram negative } & $P$. aeruginosa & 6 & & 1 & 5 & & & 0 \\
\hline & A. calcoaceticus & 1 & & & 1 & & & \\
\hline & $Y$. enterocolitica & 1 & 1 & & & & & \\
\hline & B. catarrhalis & 1 & 1 & & & & & \\
\hline & Subtotal & 27 & 16 & 2 & 9 & & & 59.3 \\
\hline & Total & 37 & 21 & 2 & 11 & 1 & 2 & 62.9 \\
\hline \multirow[t]{2}{*}{$\begin{array}{l}\text { Mixed } \\
\text { infection }\end{array}$} & Two species & 5 & 2 & 1 & 1 & 1 & & 60.0 \\
\hline & Total & 42 & 23 & 3 & 12 & 2 & 2 & 62.5 \\
\hline
\end{tabular}

Table 14 Case distribution

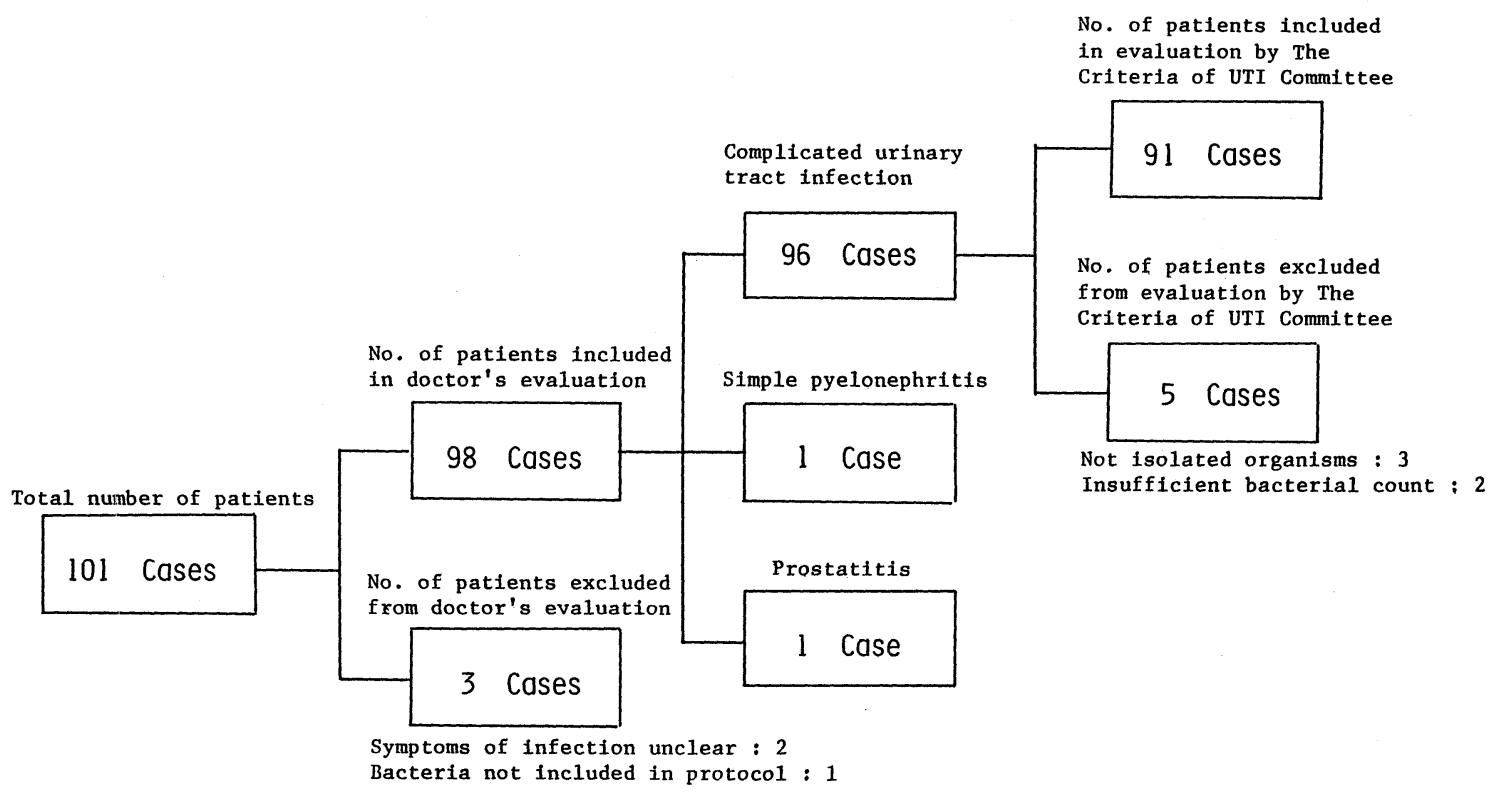


aureus の分離された 5 例中判定可能な 4 例では $50.0 \%$ の成績であった。

同様に, グラム陰性菌の分離された27例の除菌

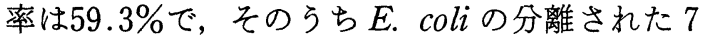
例，H. influenzaeの分離された 9 例はそれぞれ 100\%, 55.6\%の成績であったが, P. aeruginosa の 分離された 6 例では菌の消失は得られなかった。 2 菌種による混合感染 5 例は， $60.0 \%$ 除菌率で あった。

以上，起炎菌の分離された 42 症例の $5 ち 25$ 症例 で起炎菌の消失がみられ，2症例が不明で, 細菌 学的効果は $62.5 \%$ の成績であった。

2) 泌尿器科領域

泌尿器科領域に和ける HAPA-B の総症例数は 101例であった。そのうち, 感染症状が不明確のた め判定不能とした 2 例, 対象外菌種 1 例を除いた 98例の疾患別内訳は, 複雑性尿路感染症 96 例, 単 純性腎孟腎炎 1 例, 前立腺炎 1 例であった (Table 14).

複雑性尿路感染症96例のうち, UTI 薬効評価基 準での評価可能症例は91例であった，以下，これ らの91例を対象に有効性の解析を行った。

（1）患者背景因子

a ) 性別，年齢（Table 15）

91例の内訳は男性76例，女性15例で，男性 5 対 女性 1 の比率であった。年蹂は15 90歳（平均 $69.6 \pm 12.4$ 歳) で，60歳以上の高齢者が全体の $81.3 \%$ を占めた。

b) 点滴時間と溶解液量（Table 16）

1 時間点滴静注例が73例と全体の $80.2 \%$ 占 め，その他 0.5 時間が 9 例 $(9.9 \%) ， 2$ 時間が 9 例 (9.9\%)含まれていた。溶解液量は100〜 $250 \mathrm{ml}$ が 大部分で全体の $80.2 \%$ を占めたが， $300 \mathrm{ml}$ が 4 例
Table 15 Background of patients (Age, Sex)

\begin{tabular}{rcccc}
\hline \multirow{2}{*}{ Age } & \multicolumn{2}{c}{ Sex } & Total & (Rate \%) \\
\cline { 2 - 3 } & Male & Female & & \\
\hline$\sim 19$ & 1 & 0 & 1 & $(1.1)$ \\
$20 \sim 29$ & 0 & 0 & 0 & \\
$30 \sim 39$ & 0 & 0 & 0 & \\
$40 \sim 49$ & 4 & 2 & 6 & $(6.6)$ \\
$50 \sim 59$ & 8 & 2 & 10 & $(11.0)$ \\
$60 \sim 69$ & 12 & 1 & 13 & $(14.3)$ \\
$70 \sim 79$ & 41 & 7 & 48 & $(52.7)$ \\
$80 \sim$ & 10 & 3 & 13 & $(14.3)$ \\
\hline Total & 76 & 15 & 91 & $(100)$ \\
(Rate \%) & $(83.5)$ & $(16.5)$ & $(100)$ & \\
\hline \multicolumn{5}{c}{$(15 \sim 90 y .0).($ Mean \pm S.D. : $69.6 \pm 12.4 y .0)}$.
\end{tabular}

Table 16 Background of patients (Infusion time and volume)

\begin{tabular}{|c|c|c|c|c|c|c|c|}
\hline \multirow{2}{*}{$\underset{(\mathrm{hr})}{\operatorname{Time}}$} & \multicolumn{5}{|c|}{ Volume $(\mathrm{ml})$} & \multirow{2}{*}{ Total } & \multirow{2}{*}{ (Rate \%) } \\
\hline & 100 & 200 & 250 & 300 & 500 & & \\
\hline 0.5 & 2 & 5 & 2 & & & 9 & (9.9) \\
\hline 1.0 & 10 & 32 & 22 & 4 & 5 & 73 & $(80.2)$ \\
\hline 2.0 & & & & & 9 & 9 & (9.9) \\
\hline Total & 12 & 37 & 24 & 4 & 14 & 91 & (100) \\
\hline \multirow{2}{*}{ (Rate \%) } & $\underbrace{(13.2)}$ & $(40.7)$ & (26.4) & \multirow{2}{*}{\multicolumn{2}{|c|}{$(4.4)(15.4)$}} & \multirow[t]{2}{*}{ (100) } & \\
\hline & & $(80.2)$ & & & & & \\
\hline
\end{tabular}

(4.4\%)，500ml が14例 (15.4\%) 含まれていた。 従って, 泌尿器科領域に抢いても内科領域之同様 に点滴時間 1 時間, 溶解液量 $100 \sim 250 \mathrm{ml}$ の症例が 大部分であった。

c ) 投与量，投与日数（Table 17）

1 日400mg 2 回に分けて投与した例が注と んどで，わずか 2 例にのみ 1 日 $200 \mathrm{mg}$ を 1 回投与 した。投与日数は 5 日間が全体の $95.6 \%$ を占めた が，7 日間投与が 2 例 (2.2\%)，10日間投与が 2 例 $(2.2 \%)$ に認められた。

Table 17 Background of patients (Dose, Duration)

\begin{tabular}{|c|c|c|c|c|c|c|c|c|c|c|c|c|}
\hline \multirow{2}{*}{$\underset{(\mathrm{mg} \times \text { times } / \text { day })}{\text { Dose }}$} & \multicolumn{10}{|c|}{ Duration (days) } & \multirow{2}{*}{ Total } & \multirow{2}{*}{ (Rate \%) } \\
\hline & 3 & 4 & 5 & 6 & 7 & 8 & 9 & 10 & 11 & 12 & & \\
\hline $200 \times 1$ & & & 2 & & & & & & & & 2 & $(2.2)$ \\
\hline $200 \times 2$ & & & 85 & & 2 & & & 2 & & & 89 & $(97.8)$ \\
\hline $\begin{array}{c}\text { Total } \\
\text { (Rate \%) }\end{array}$ & & & $\begin{array}{c}87 \\
(95.6)\end{array}$ & & $\begin{array}{c}2 \\
(2.2)\end{array}$ & & & $\begin{array}{c}2 \\
(2.2)\end{array}$ & & & $\begin{array}{c}91 \\
(100)\end{array}$ & $(100)$ \\
\hline
\end{tabular}


（2）臨床効果

a ）UTI 薬効評価基準による臨床効果

91症例をUTI薬効評価基準の疾患病態別に従っ て分類し，その総合臨床効果を Table 18 に示し た.

単独感染群69例 $(75.8 \%)$ のち , 著効十有効 は39例で，有効率は56.5\%であった。そのらち第 1 群は33例 (36.3\%)，第 2 群は 21 例 (23.1\%), 第 3 群は 5 例 (5.5\%)，第 4 群は10例 (11.0\%) で，有効率はそれぞれ54.5\%，47.6\%，40.0\%，
$90.0 \%$ であった.第 4 群は症例数が少ないものの, $90.0 \%$ 之良好な結果が得られた。一方, 混合感染 群22例 (24.2\%) の5ち著効十有効は11例で, 有 効率は50.0\%であった。 そのらち第 5 群が 8 例 (8.8\%)，第 6 群が 14 例 (15.4\%) で，有効率はそ れぞれ37.5\%，57.1\%であった。また，カテーテ ル留置群41例(45.1\%)の有効率は $51.2 \%$ ，カテー テル非留置群50例(54.9\%)のそれは $58.0 \%$ のっ た。

Table 19に膿尿と細菌尿に関する効果を示した.

Table 18 Overall clinical efficacy of HAPA-B classified by type of infection

\begin{tabular}{|c|c|c|c|c|c|c|}
\hline & Group & $\begin{array}{c}\text { No. of cases } \\
\text { (Rate) }\end{array}$ & Excellent & Moderate & Poor & $\begin{array}{l}\text { Overall } \\
\text { effectiveness } \\
\text { rate }\end{array}$ \\
\hline \multirow{5}{*}{$\begin{array}{l}\text { Single } \\
\text { infection }\end{array}$} & $\begin{array}{l}\text { 1st group } \\
\text { (Catheter indwelt) }\end{array}$ & $\begin{array}{c}33 \\
(36.3 \%)\end{array}$ & 5 & 13 & 15 & $54.5 \%$ \\
\hline & $\begin{array}{l}\text { 2nd group } \\
\text { (Post prostatectomy) }\end{array}$ & $\begin{array}{c}21 \\
(23.1 \%)\end{array}$ & 3 & 7 & 11 & $47.6 \%$ \\
\hline & $\begin{array}{l}\text { 3rd group } \\
\text { (Upper U.T.I.) }\end{array}$ & $\begin{array}{c}5 \\
(5.5 \%)\end{array}$ & 1 & 1 & 3 & $40.0 \%$ \\
\hline & $\begin{array}{l}\text { 4th group } \\
\text { (Lower U.T.I.) }\end{array}$ & $\begin{array}{c}10 \\
(11.0 \%) \\
\end{array}$ & 6 & 3 & 1 & $90.0 \%$ \\
\hline & Subtotal & $\begin{array}{c}69 \\
(75.8 \%) \\
\end{array}$ & 15 & 24 & 30 & $56.5 \%$ \\
\hline \multirow{4}{*}{$\begin{array}{l}\text { Mixed } \\
\text { infection }\end{array}$} & $\begin{array}{l}\text { 5th group } \\
\text { (Catheter indwelt) }\end{array}$ & $\begin{array}{c}8 \\
(8.8 \%)\end{array}$ & 1 & 2 & 5 & $37.5 \%$ \\
\hline & $\begin{array}{l}\text { 6th group } \\
\text { (No catheter indwelt) }\end{array}$ & $\begin{array}{c}14 \\
(15.4 \%) \\
\end{array}$ & & 8 & 6 & $57.1 \%$ \\
\hline & Subtotal & $(24.2 \%)$ & 1 & 10 & 11 & $50.0 \%$ \\
\hline & Total & $\begin{array}{c}91 \\
(100 \%)\end{array}$ & 16 & 34 & 41 & $54.9 \%$ \\
\hline
\end{tabular}

Table 19 Overall clinical efficacy of HAPA-B in complicated U.T.I.

\begin{tabular}{|c|c|c|c|c|}
\hline Bacteriuria & Cleared & Decreased & Unchanged & Efficacy on bacteriuria \\
\hline Eliminated & 16 & 9 & 16 & $41 \quad(45.1 \%)$ \\
\hline Decreased & 1 & 1 & 2 & $4 \quad(4.4 \%)$ \\
\hline Replaced & 0 & 5 & 11 & $16 \quad(17.6 \%)$ \\
\hline Unchanged & 7 & 1 & 22 & $30 \quad(33.0 \%)$ \\
\hline Efficacy on pyuria & $\begin{array}{c}24 \\
(26.4 \%) \\
\end{array}$ & $\begin{array}{c}16 \\
(17.6 \%)\end{array}$ & $\begin{array}{c}51 \\
(56.0 \%)\end{array}$ & Case total 91 \\
\hline $\begin{array}{r}\mathrm{Exc} \\
\mathrm{Moc} \\
\square \mathrm{PoO}\end{array}$ & & $\begin{array}{l}16(17.6 \%) \\
34(37.4 \%) \\
41(45.1 \%)\end{array}$ & \multicolumn{2}{|c|}{$\begin{array}{l}\text { Overall effectiveness rate } \\
\qquad 54.9 \%(50 / 91)\end{array}$} \\
\hline
\end{tabular}


膿尿に関しては正常化，改善，不変がそれぞれ24 例 $(26.4 \%), 16$ 例 (17.6\%)，51例（56.0\%）で, 細菌尿に関しては陰性化，減少，菌交代，不変が それぞれ41例 (45.1\%)，4 例 (4.4\%)，16例 (17.6\%)，30例（33.0\%）であった。

以上, UTI 薬効評価基準に基づく91症例に対す る総合臨床効果は著効 16 例, 有効 34 例, 無効 41 例 で，総合有効率は $54.9 \%$ であった。

b ) 分離菌別臨床効果（UTI 薬効評価基準）

分離菌別臨床効果をTable 20 に示した。グラ 么陽性菌単独感染群では有効率 $45.5 \%(5 / 11)$ と やや劣る成績であった。 とくに E. faecalis 5 例の 有効率は $40.0 \%$ にどまった。
グラム陰性菌単独感染群での全体の有効率は $58.6 \%(34 / 58)$ で，グラム陽性菌群に比して優れ て㧍り，P. aeruginosa 25例には56.0\%（14/25） の有効率を示した。一方, 混合感染群 22 例の有効 率は $50.0 \%$ あっった。

c) 点滴時間別臨床効果 (UTI 薬効評価基準)

Table 21 に点滴時間別臨床効果の成績を示し た. 症例数の多い点滴時間 1 時間の有効率は $56.2 \%(41 / 73)$ であった。 また，少数例ではある が0.5時間の有効率は $55.6 \%$ (5/9) で， 1 時間の 成績とほぼ同等であった。しかし，点滴時間 2 時 間の有効率は $44.4 \%(4 / 9)$ で，0.5時間，1 時間 の成績に比べてやや低い有効率であった。

Table 20 Clinical efficacy of HAPA-B classified by isolated organisms

\begin{tabular}{|c|c|c|c|c|c|c|c|}
\hline & & \multirow{2}{*}{ Organisms } & \multirow{2}{*}{ No. of cases } & \multicolumn{3}{|c|}{ Clinical effects } & \multirow{2}{*}{$\begin{array}{c}\text { Efficacy* } \\
\text { rate } \\
(\%)\end{array}$} \\
\hline & & & & Excellent & Moderate & Poor & \\
\hline \multirow{5}{*}{\multicolumn{2}{|c|}{ Gram positive }} & S. aureus & 2 & 1 & & 1 & \\
\hline & & S. epidermidis & 3 & & 2 & 1 & 66.7 \\
\hline & & E. faecalis & 5 & 1 & 1 & 3 & 40.0 \\
\hline & & Streptococcus & 1 & & & 1 & \\
\hline & & Subtotal & 11 & 2 & 3 & 6 & 45.5 \\
\hline \multirow{7}{*}{\multicolumn{2}{|c|}{$\begin{array}{l}\text { Single } \\
\text { infection }\end{array}$}} & E. coli & 1 & & 1 & & \\
\hline & & C. freundii & 2 & & 2 & & \\
\hline & & $K$. pneumoniae & 3 & & 2 & 1 & 66.7 \\
\hline & & Klebsiella & 2 & 1 & 1 & & \\
\hline & & E. cloacae & 3 & & 2 & 1 & 66.7 \\
\hline & & E. agglomerans & 1 & & & 1 & \\
\hline & & Enterobacter & 1 & 1 & & & \\
\hline \multirow[t]{10}{*}{ Gram n } & gative & S. marcescens & 4 & 2 & 2 & & 100 \\
\hline & & S. liquefaciens & 1 & & & 1 & \\
\hline & & Serratia & 4 & & 1 & 3 & 25.0 \\
\hline & & Proteus & 2 & 2 & & & \\
\hline & & P. aeruginosa & 25 & 6 & 8 & 11 & 56.0 \\
\hline & & Pseudomonas & 5 & 1 & 1 & 3 & 40.0 \\
\hline & & A. calcoaceticus & 2 & & 1 & 1 & \\
\hline & & NF-GNR** & 2 & & & 2 & \\
\hline & & Subtotal & 58 & 13 & 21 & 24 & 58.6 \\
\hline & & Total & 69 & 15 & 24 & 30 & 56.5 \\
\hline \multirow{5}{*}{$\begin{array}{l}\text { Mixed } \\
\text { infection }\end{array}$} & Gram & positive + Gram positive & 3 & & 2 & 1 & 66.7 \\
\hline & Gram & positive + Gram negative & 10 & 1 & 5 & 4 & 60.0 \\
\hline & Gram & negative + Gram negative & 9 & & 3 & 6 & 33.3 \\
\hline & & Total & 22 & 1 & 10 & 11 & 50.0 \\
\hline & & Total & 91 & 16 & 34 & 41 & 54.9 \\
\hline
\end{tabular}

${ }^{*}$ Efficacy rate $=\frac{\text { Excellent }+ \text { Moderate }}{\text { Excellent }+ \text { Moderate }+ \text { Poor }} \times 100,{ }^{* *}$ Non fermentating gram negative rod 
Table 21 Clinical efficacy of HAPA-B classified by infusion time

\begin{tabular}{|c|c|c|c|c|c|}
\hline \multirow{2}{*}{$\underset{(\mathrm{hr})}{\text { Time }}$} & \multirow{2}{*}{ No. of cases } & \multicolumn{3}{|c|}{ Clinical effects } & \multirow{2}{*}{ Efficacy rate (\%)* } \\
\hline & & Excellent & Moderate & Poor & \\
\hline 0.5 & 9 & 2 & 3 & 4 & 55.6 \\
\hline 1.0 & 73 & 14 & 27 & 32 & 56.2 \\
\hline 2.0 & 9 & & 4 & 5 & 44.4 \\
\hline Total & 91 & 16 & 34 & 41 & 54.9 \\
\hline
\end{tabular}

Table 22 Doctor's evaluation of HAPA-B classified by diagnosis

\begin{tabular}{|c|c|c|c|c|c|c|c|c|}
\hline & \multirow{2}{*}{\multicolumn{2}{|c|}{ Diagnosis }} & \multirow{2}{*}{$\begin{array}{l}\text { No. of } \\
\text { cases }\end{array}$} & \multicolumn{4}{|c|}{ Clinical effects } & \multirow{2}{*}{$\begin{array}{l}\text { Efficacy* } \\
\text { rate (\%) }\end{array}$} \\
\hline & & & & Excellent & Good & Fair & Poor & \\
\hline \multirow{3}{*}{ UTI } & Simple & Pyelonephritis & 1 & 1 & & & & \\
\hline & \multirow{2}{*}{ Complicated } & Cystitis & 76 & 18 & 24 & 13 & 21 & 55.3 \\
\hline & & Pyelonephritis & 20 & 2 & 14 & 2 & 2 & 80.0 \\
\hline \multicolumn{3}{|c|}{ Prostatitis } & 1 & & 1 & & & \\
\hline \multicolumn{3}{|c|}{ Total } & 98 & 21 & 39 & 15 & 23 & 61.2 \\
\hline
\end{tabular}

Table 23 Bacteriological response to HAPA-B in complicated U.T.I.

\begin{tabular}{|c|c|c|c|c|}
\hline & Organisms & No. of strains & Eradicated (\%) & Persisted ${ }^{*}$ \\
\hline \multirow{6}{*}{ Gram positive } & S. aureus & 2 & 1 & 1 \\
\hline & S. epidermidis & 9 & $8(88.9)$ & 1 \\
\hline & E. faecalis & 14 & $6(42.9)$ & 8 \\
\hline & Staphylococcus & 1 & 1 & 0 \\
\hline & Streptococcus & 2 & 1 & 1 \\
\hline & Subtotal & 28 & $17(60.7)$ & 11 \\
\hline \multirow{18}{*}{ Gram negative } & E. coli & 4 & $4(100)$ & 0 \\
\hline & Citrobacter & 6 & $6(100)$ & 0 \\
\hline & K. pneumoniae & 4 & $4(100)$ & 0 \\
\hline & Klebsiella & 2 & 2 & 0 \\
\hline & E. cloacae & 3 & $3(100)$ & 0 \\
\hline & Enterobacter & 2 & 2 & 0 \\
\hline & S. marcescens & 6 & $6(100)$ & 0 \\
\hline & Serratia & 8 & $4(50.0)$ & 4 \\
\hline & P. mirabilis & 3 & $2(66.7)$ & 1 \\
\hline & Indole $(+)$ Proteus & 4 & $4(100)$ & 0 \\
\hline & P. aeruginosa & 32 & $21(65.6)$ & 11 \\
\hline & Pseudomonas & 8 & $5(62.5)$ & 3 \\
\hline & Acinetobacter & 6 & $2(33.3)$ & 4 \\
\hline & A. odorans & 1 & 0 & 1 \\
\hline & K. cryocrescens & 1 & 0 & 1 \\
\hline & NF-GNR ** & 2 & 0 & 2 \\
\hline & Subtotal & 92 & $65(70.7)$ & 27 \\
\hline & Total & 120 & $82(68.3)$ & 38 \\
\hline
\end{tabular}


d）疾患別主治医判定

HAPA-B が投与された総症例101例のらち，主 治医判定の可能な98例に対する疾患別主治医判定 の成績をTable 22 に示した. 主治医判定では著 効21例, 有効39例, やや有効15例, 無効23例とな り，有効率は $61.2 \%$ であった。 そのうち複雑性膀 胼炎に対しては $55.3 \%(42 / 76)$ の有効率であった が，複雑性腎孟腎炎には80.0\% (16/20) と優れた
成績であった。

（3）分離菌別細菌学的効果（UTI 薬効評価基 準)

分離菌別細菌学的効果を Table 23 に示した。 起炎菌として分離された株は120株で, そのうちグ ラム陽性菌は 28 株 $(23.3 \%)$ 中17株が消失し，消 失率は60.7\%であった。グラム陰性菌は92株 （76.7\%）が分離され，そのらちの65株が消失し，

Table 24 Strains appearing after HAPA-B treatment in complicated U.T.I.

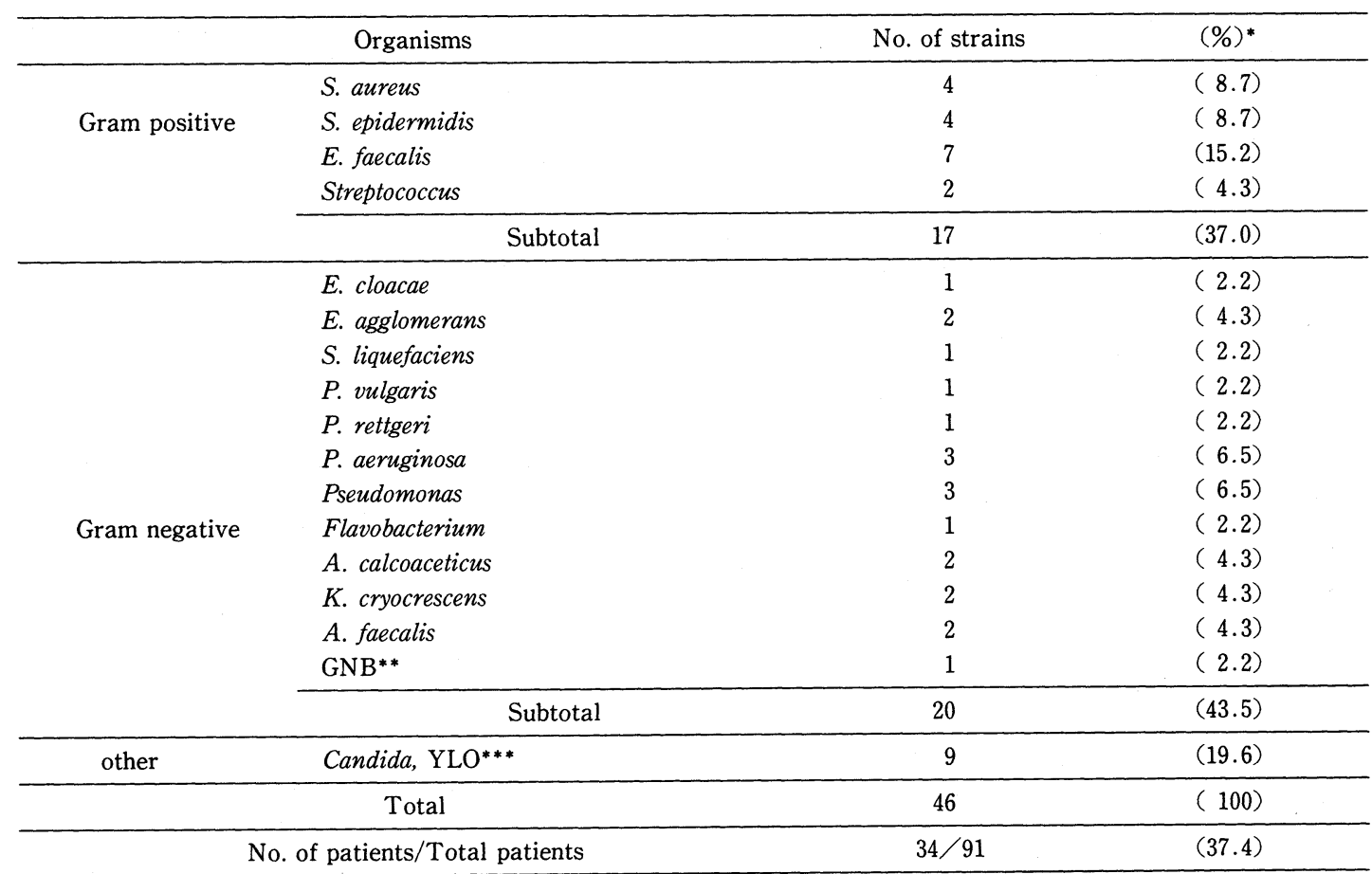

*Regardless of bacterial count, ${ }^{* *}$ Gram negative rod, ${ }^{* * *}$ Yeast like organisms

Table 25 Side effects

\begin{tabular}{|c|c|c|c|c|c|c|c|}
\hline Case & $\begin{array}{l}\text { Side effect } \\
\text { (Degree) }\end{array}$ & $\begin{array}{l}\text { Age } \\
\text { Sex } \\
\text { Weight }\end{array}$ & $\begin{array}{c}\text { Diagnosis } \\
\text { (Underlying disease) }\end{array}$ & $\begin{array}{l}\text { Dose } \\
\text { /day }\end{array}$ & $\begin{array}{l}\text { Appea- } \\
\text { rance }\end{array}$ & $\begin{array}{l}\text { Continuation } \\
\text { of admini- } \\
\text { stration }\end{array}$ & Progress \\
\hline 1 & $\begin{array}{l}\text { Anorexia } \\
\text { (Mild) }\end{array}$ & $\begin{array}{c}74 \\
\mathrm{M} \\
50.5 \mathrm{~kg}\end{array}$ & $\begin{array}{l}\text { Chronic complicated } \\
\text { cystitis } \\
\text { (Benign prostatic } \\
\text { hyperplasia) }\end{array}$ & $\underset{\times 2}{200 \mathrm{mg}}$ & $\begin{array}{l}1 \text { st } \\
\text { day }\end{array}$ & $\begin{array}{l}\text { continued } \\
5 \text { days }\end{array}$ & $\begin{array}{l}\text { Continued administration of HAPA- } \\
\text { B without treatment. After adminis- } \\
\text { tration, anorexia disappeared grad- } \\
\text { ually. }\end{array}$ \\
\hline 2 & $\begin{array}{c}\text { Fever } \\
\text { (Moderate) }\end{array}$ & $\stackrel{86}{\mathrm{~F}}$ & $\begin{array}{l}\text { Pneumonia } \\
\text { (Dementia) }\end{array}$ & $\underset{\times 2}{200 \mathrm{mg}}$ & $\begin{array}{l}8 \text { th } \\
\text { day }\end{array}$ & discontinued & $\begin{array}{l}\text { After discontinued administration } \\
\text { of HAPA-B, at } 4 \text { th day, body tem- } \\
\text { perature returned to normal. But } \\
\text { sometimes thereafter appearance of } \\
\text { fever of undetermined origin. }\end{array}$ \\
\hline 3 & $\begin{array}{l}\text { Eruption } \\
\text { (Mild) }\end{array}$ & $\begin{array}{l}76 \\
\mathrm{~F} \\
49.5 \mathrm{~kg}\end{array}$ & $\begin{array}{l}\text { Sepsis } \\
\text { (Cerebral infarction } \\
\quad \text { Neurogenic bladder) }\end{array}$ & $\underset{\times 2}{200 \mathrm{mg}}$ & $\begin{array}{l}\text { 4th } \\
\text { day }\end{array}$ & discontinued & $\begin{array}{l}\text { After discontinued administration } \\
\text { of HAPA-B, at 3rd day, eruption } \\
\text { disappeared without treatment. }\end{array}$ \\
\hline
\end{tabular}


消失率は $70.7 \%$ であった。

分離菌別臨床効果の成績と同様, グラム陰性菌 の消失率がグラム陽性菌に比べてやや良好な成績 であった。全体では82株が消失し，消失率は $68.3 \%$ であった．32株（26.7\%）が分離された P. aeruginosaの消失率は65.6\% (21/32) と優れていた が, E. faecalis は42.9\%(6/14), Acinetobacter は $33.3 \%(2 / 6)$ とやや劣る成績であった.

(4) 投与後出現菌

HAPA-B 投与後出現した菌種と株数を Table 24 に示した。症例91例中34例 (37.4\%) に拈いて 46株が出現した。その内訳はグラム陽性菌が17株
(37.0\%)，グラム陰性菌20株（43.5\%）であった が, Candida，酵母様真菌(YLO)が 9 株(19.6\%) みられた。

\section{3. 副作用の検討}

HAPA-B が投与された内科領域 81 例, 泌尿器科 領域101例の計182例について副作用, 臨床検査値 などの安全性に関して検討を行った。

自・他覚的副作用の認められた症例は 3 例 (1.6\%)で，その内訳は食欲不振 1 例，発熱 1 例, 皮疹 1 例であった(Table 25). 食欲不振の 1 例は 本剂投与 1 日目に出現したが，未処置のまま 5 日 間投与を継続し，投与終了後次第に消失した。発

Table 26 Abnormal laboratory findings

\begin{tabular}{|c|c|c|c|c|c|c|c|c|}
\hline \multirow{3}{*}{$\begin{array}{l}\text { Sex } \\
\text { Age } \\
\text { B.W. } \\
\text { (kg) }\end{array}$} & \multirow{3}{*}{ Diagnosis } & \multirow{3}{*}{$\begin{array}{l}\text { Underlying } \\
\text { disease }\end{array}$} & \multicolumn{3}{|c|}{ Laboratory findings } & \multirow{3}{*}{$\begin{array}{l}\text { Administration } \\
\text { Daily dose } \\
\text { (mg × times) } \\
\text { \& Duration } \\
\text { (days) }\end{array}$} & \multirow{3}{*}{$\begin{array}{l}\text { Causal } \\
\text { relation } \\
\text { of drug }\end{array}$} & \multirow{3}{*}{ Doctor's comment } \\
\hline & & & \multirow{2}{*}{ Items } & \multicolumn{2}{|c|}{ Value } & & & \\
\hline & & & & Before & After & & & \\
\hline $\begin{array}{c}M \\
75 \\
54.5\end{array}$ & $\begin{array}{l}\text { Pulmonary } \\
\text { fibrosis } \\
\text { +infection }\end{array}$ & $\begin{array}{l}\text { Pulmonary } \\
\text { fibrosis } \\
\text { Pulmonary } \\
\text { cyst }\end{array}$ & $\begin{array}{c}\mathrm{RBC} \text { in } \\
\text { urine } \\
\text { (microscope) }\end{array}$ & $10-20$ & $40-50$ & $\begin{array}{c}200 \times 2 \\
4\end{array}$ & Probable & Slight elevation. \\
\hline $\begin{array}{l}\mathrm{F} \\
44 \\
38\end{array}$ & Bronchiectasis & $\begin{array}{l}\text { Chronic } \\
\text { nephritis }\end{array}$ & $\begin{array}{l}\text { ALP } \\
\text { LDH }\end{array}$ & $\begin{array}{l}63 \\
97\end{array}$ & $\begin{array}{r}90 \\
122\end{array}$ & $\begin{array}{c}200 \times 2 \\
3\end{array}$ & Possible & $\begin{array}{l}\text { Slight elevation. Returned } \\
\text { to normal level (ALP : } 69 \text {, } \\
\text { LDH : 97) 10th day after } \\
\text { administration }\end{array}$ \\
\hline $\begin{array}{l}F \\
52 \\
45\end{array}$ & $\begin{array}{l}\text { Acute } \\
\text { pneumonia }\end{array}$ & - & $\begin{array}{l}\text { GOT } \\
\text { GPT }\end{array}$ & $\begin{array}{l}17 \\
12\end{array}$ & $\begin{array}{l}48 \\
47\end{array}$ & $\begin{array}{c}200 \times 2 \\
15\end{array}$ & Probable & $\begin{array}{l}\text { Slight elevation. Returned } \\
\text { to normal level (GOT: }: 31 \text {, } \\
\text { GPT }: 26 \text { ) without treat- } \\
\text { ment } 11 \text { th day after admini- } \\
\text { stration. }\end{array}$ \\
\hline $\begin{array}{l}M \\
50 \\
55\end{array}$ & Pneumonia & $\begin{array}{l}\text { The sprain } \\
\text { of L-knee }\end{array}$ & $\begin{array}{l}\text { GOT } \\
\text { GPT }\end{array}$ & $\begin{array}{l}20 \\
14\end{array}$ & $\begin{array}{l}37 \\
57\end{array}$ & $\begin{array}{c}200 \times 2 \\
14\end{array}$ & Probable & $\begin{array}{l}\text { Slight elevation. Returned } \\
\text { to normal level (GOT : } 22 \text {, } \\
\text { GPT : 15) without treat- } \\
\text { ment } 19 \text { th day after admini- } \\
\text { stration. }\end{array}$ \\
\hline $\begin{array}{l}\mathrm{F} \\
52 \\
55\end{array}$ & Pneumonia & - & $\begin{array}{l}\text { GOT } \\
\text { GPT }\end{array}$ & $\begin{array}{l}43 \\
30\end{array}$ & $\begin{array}{l}59 \\
55\end{array}$ & $\begin{array}{c}200 \times 2 \\
13\end{array}$ & Probable & $\begin{array}{l}\text { Slight elevation. Returned } \\
\text { to normal level (GOT : } 23 \text {, } \\
\text { GPT }: 32 \text { ) without treat- } \\
\text { ment } 16 \text { th day after admini- } \\
\text { stration. }\end{array}$ \\
\hline $\begin{array}{c}\mathrm{F} \\
86\end{array}$ & Pneumonia & Dementia & $\mathrm{K}^{+}$in serum & 3.7 & 2.9 & $\begin{array}{c}200 \times 2 \\
10\end{array}$ & Possible & Slight decrease. \\
\hline $\begin{array}{l}\mathrm{F} \\
75 \\
46\end{array}$ & Pyelonephritis & $\begin{array}{l}\text { Gastric } \\
\text { ulcer }\end{array}$ & $\begin{array}{l}\text { GOT } \\
\text { GPT }\end{array}$ & $\begin{array}{c}18 \\
8\end{array}$ & $\begin{array}{l}77 \\
49\end{array}$ & $\begin{array}{c}200 \times 2 \\
10\end{array}$ & Definite & $\begin{array}{l}\text { Moderate elevation. Retur- } \\
\text { ned to normal level } \\
\text { (GOT : } 18 \text {, GPT : 14) 5th } \\
\text { day after discontinuance of } \\
\text { administration. }\end{array}$ \\
\hline $\begin{array}{l}\mathrm{M} \\
43 \\
54\end{array}$ & $\begin{array}{l}\text { Chronic } \\
\text { pyelonephritis }\end{array}$ & $\begin{array}{l}\text { Bladder } \\
\text { tumor }\end{array}$ & $\begin{array}{l}\text { GPT } \\
\text { ALP }\end{array}$ & $\begin{array}{c}38 \\
134\end{array}$ & $\begin{array}{c}58 \\
165\end{array}$ & $\begin{array}{c}200 \times 2 \\
5\end{array}$ & Possible & $\begin{array}{l}\text { Slight elevation. Returned } \\
\text { to normal level (GPT }: 32 \text {, } \\
\text { ALP : 148) 9th day after } \\
\text { administration. }\end{array}$ \\
\hline $\begin{array}{l}\mathrm{F} \\
70 \\
42\end{array}$ & Chronic cystitis & $\begin{array}{l}\text { Gastric } \\
\text { cancer } \\
\text { Prolapse } \\
\text { vesicae } \\
\text { Chr. hepatitis }\end{array}$ & $\begin{array}{l}\text { GOT } \\
\text { GPT } \\
\text { ALP }\end{array}$ & $\begin{array}{c}58 \\
32 \\
229\end{array}$ & $\begin{array}{c}86 \\
48 \\
321\end{array}$ & $\begin{array}{c}200 \times 2 \\
5\end{array}$ & Possible & $\begin{array}{l}\text { Slight elevation. Dropped } \\
\text { (GOT : 68, GPT : } 36 \text {, } \\
\text { ALP : 260) 8th day after } \\
\text { administration. May be } \\
\text { caused by chr. hepatitis. }\end{array}$ \\
\hline
\end{tabular}


熱の 1 例は投与 8 日目に出現し，本剤に起因する drug fever として疑われ，本剤の投与中止により 解熱をみた。しかし，その後に沶いても原因不明 の発熱がみられたことから，本剂との因果関係は 明らかではないと判定された。皮疹の 1 例は投与 4 日目に出現し，本剤に起因するものと疑われて 投与を中止した。 その後処置をすることなく 3 日 目には消失した。

臨床検查値の異常は Table 26 に示したとおり である。その内訳はGOT, GPT, LDH, ALPな ぞ肝機能異常 7 例, 顕微鏡的血尿の軽度増加 1 例, 血清 $\mathrm{K}^{+}$の軽度低下 1 例の計 9 例であった. GOT・ $\mathrm{GPT}$ 上昇の 4 例, $\mathrm{GPT} \cdot \mathrm{ALP}$ 上昇, $\mathrm{ALP} \cdot \mathrm{LDH}$ 上昇の各 1 例はいずれも一過性の変動で, 投与後 （5日～19日）正常に復した.GOT・GPT・ALP 上昇の 1 例も一過性の変動で, 本剂に起因すると 考光られたが，本例は慢性肝炎を合併しており， それによる可能性も考えられた。顕微鏡的血尿の 増加例抢よび血清 $\mathrm{K}^{+}$の低下例は他に要因がな く, 本剂との因果関係が疑われたが，ともに軽微 な変動であった。

聴力検査として 4 症例に対して本剂投与前後に オージオグラムを，38症例に対して音叉・ストッ プウオッチ・医師の問診による検査を施行したが, いずれも異常変動は認められなかった(Table 27).

\section{III. 総括並びに考察}

HAPA-Bに関しては筋注投与に和ける基礎 的・臨床的研究が現在までに数多く実施され，第 31 回日本化学療法学会東日本支部総会に括いて 総合的に評価された ${ }^{2)}$. HAPA-B は AAC ( $\left.6^{\prime}\right)-4$ を除く各種 $\mathrm{AGs}$ 剂不活化酵素に安定で, グラム陽 性菌拉よびグラム陰性菌に対して幅広く，かつ殺 菌的に作用する。安全性に関してはラット・モル モットなどを用いた動物実験より，GM は勿論の こと AMKより腎毒性, 耳毒性, 神経-筋伝達抑制

Table 27 Audiometry

\begin{tabular}{cccc}
\hline Methods & $\begin{array}{c}\text { No. of } \\
\text { subjects }\end{array}$ & $\begin{array}{c}\text { No. of cases with } \\
\text { abnormal change } \\
\text { (Appearance rate\%) }\end{array}$ \\
\hline $\begin{array}{c}\text { Audiogram } \\
\text { Fork and so on }\end{array}$ & 48 & 0 & $(0)$ \\
\hline
\end{tabular}

作用などが低いと報告されている。臨床成績に関 しては内科領域では肺炎で75.5\% (74/98), 慢性 気管支炎で54.8\%(23/42), 呼吸器感染症全体で は62.5\% (130/208) の有効率であった。一方，泌 尿器科領域では主治医判定で59.9\% (208/347), UTI 薬効評価基準による判定では57.0\%（159/ 279）の有効率であった。副作用は745例中 7 例に みられ，発現率は $0.9 \%$ であった。

今回，我々は全国28施設およびその関連施設に 扔いて, 内科領域, 泌尿器科領域の諸感染症に対 するHAPA-B 点滴静注の有効性扝よび安全性に ついて基礎的・臨床的研究を行った。

本剂 $200 \mathrm{mg}$ を患者に0.5時間ないしは 1 時間か けて点滴静注した場合の初回投与時の血中濃度の ピークは, いずれも点滴終了時にあり, その值は それぞれ $12.05 \sim 16.59 \mu \mathrm{g} / \mathrm{ml}, 8.64 \sim 22.54 \mu \mathrm{g} / \mathrm{ml}$ で, 平均濃度は $14.57 \pm 1.54 \mu \mathrm{g} / \mathrm{ml}, 14.13 \pm 4.44$ $\mu \mathrm{g} / \mathrm{ml}$ であった。 1 時間点滴に比べて 0.5 時間点 滴時の平均濃度がやや高値を示したが， 1 時間点 滴静注の場合はバラッキが大きく, $20 \mu \mathrm{g} / \mathrm{ml}$ 以上 の症例が 3 例経験された。 3 例は，それぞれ脳梗 塞を基礎疾患とする気管支肺炎の患者（男性， 66 歳, $58 \mathrm{~kg}$ ), 前立腺癌を基礎疾患とする膀胱炎の患 者 (男性, 79歳, $41 \mathrm{~kg}$ ), 神経因性膀胱を基礎疾患 とする膀脱炎の患者 (女性, 45歳, $38 \mathrm{~kg}$ )であり, この原因として, 高齢, 低体重, 腎機能障害など の患者背景に基づく可能性が考えられた。本剂と 活湆同様の体内動態を示す $\mathrm{AMK}^{2)}$ で患者の血 中濃度測定に和いて200mg 1 時間点滴静注で20 $\mu \mathrm{g} / \mathrm{ml}$ 以上の高值を示した例がみられ ${ }^{8) 9}$, 患者背 景により血中濃度が高值になりらることが示唆さ れた。 Barza M.等 ${ }^{10)}$ は, AMKの毒性領域はピー ク值で30 35 $\mu \mathrm{g} / \mathrm{ml}$ 以上と報告している. HAPA-B は動物を用いた基礎実験の結果から,一 般毒性，腎毒性执よび耳毒性は AMKょり弱いと 報告されていること到より，本剤の毒性領域は $\mathrm{AMK}$ と同等あるいはそれ以上と考㝋られる。今 回のピーク值はいずれも $30 \mu \mathrm{g} / \mathrm{ml}$ 以下であり，泀 ぼ安全域内の変動と考えられた。事実, 血中濃度 が $20 \mu \mathrm{g} / \mathrm{ml}$ 以上 $(20.85 ， 22.33 ， 22.54)$ を呈した 患者に敃いても，本剂に基づく副作用や臨床検査 
値異常は認められなかった。

また，1時間点滴静注で連続投与（3１4回投 与）した際の血中濃度のピークは点滴終了時にあ り，その值は7.18 $16.76 \mu \mathrm{g} / \mathrm{ml}$ で，平均濃度は $13.13 \pm 3.03 \mu \mathrm{g} / \mathrm{ml}$ であった。 ピーク值の平均血 中濃度, 血中濃度推移はともに初回投与時と汪注 同様の成績であった。血中濃度推移は 0.5 時間， 1 時間点滴静注いずれの投与でも点滴静注終了後比 較的すみやかに減少したが， Ccr $69.7 \mathrm{ml} / \mathrm{min}$. 以 上の患者に比べて, Ccr $50.7 \mathrm{ml} / \mathrm{min}$. 以下の患者 では血中濃度の持続遷延する傾向が認められた。 この成績は腎機能正常者および障害者 (Ccr 30.6 $\sim 62.6 \mathrm{ml} / \mathrm{min}$.) に対して本剂を 1 時間点滴静注 したときの成績と一致し, 血中濃度に関しては腎 機能低下に従い明らかに血中濃度の持続遷延傾向 が認められた。投与 8 時間後に打ける腎機能正常 群, 軽度障害群, 中等度障害群の平均血中濃度は, それぞれ1.81, $3.10,4.87 \mu \mathrm{g} / \mathrm{ml}$ であった. Ccr と $\mathrm{T}_{1 / 2}(\beta)$ の間にも関連性がみられ，Ccrの低下に 従って $T_{1 / 2}(\beta)$ が延長した。 また12時間累積尿中 回収率も腎機能障害者では正常者に比して低下し た。従来より, AGs 剤は薬効量の幅が狭いという 難点があり，点滴静注投与にあたっても筋注の際 と同様に腎機能，年齢，体重などの患者背景を充 分に考慮しながら投与すべきであると考劣る。

慢性気管支炎患者 1 例（64歳，女性， $33 \mathrm{~kg}$ ）に 本剂200mgを 1 時間かけて点滴静注したときの 血中，尿中，喀痰中濃度㘧よび尿中回収率を検討 したところ，喀痰中濃度のピーク值は $1 \sim 3$ 時間 後にみられ $1.03 \mu \mathrm{g} / \mathrm{g}$ で，筋注での喀痰中移行性 とほぼ同等と考えられた ${ }^{11)}$.

臨床的検討では内科領域に扮いて本剂が81例の 患者に投与されたが， 7 例が除外・脱落例のため 74例に対して有効性の評価を行った。74例の患者 背景をみると, 60 歳以上の高齢者が約 $50 \%$ 占め, 男性対女性の比率は 2 対 1 であった。投与方法は 本剤200mg を 1 日 2 回, $100 \sim 250 \mathrm{ml}$ の生理食塩 液, 糖液, 電解質液などに溶解し，1時間かけて 点滴静注する例が全体の $83.8 \%$ を占めた。投与日 数は 7 １4日間が多かったが，尿路感染症では 7 日以内が多く, 呼吸器感染症では15日以上の長期
投与例が 12 例 $(16.2 \%)$ にみられた。臨床成績は 内科領域全体で $75.7 \%(56 / 74)$ の有効率で，注ぼ 満足のいく結果であった。そのうち呼吸器感染症 では肺炎が81.5\% (22/27) と優れた成績であった が，肺炎とほぼ同数で呼吸器感染症全体の 4 割強 を占めた慢性気道感染症では $52.0 \%(13 / 25)$ と劣 り, 全体では70.5\%（43/61）の有効率であった。 慢性気道感染は一般に呼吸器感染症のなかでは難 治群の中心を占めるものであり，これは気道の解 剖学的変化を基盤に感染が続発性に反復し，この 修復による線維化の進展により，全身投与では有 効な病巣内濃度が得られ難い疾患背景があること も一因と考えられる。このような症例群に対する 本剂の有効率 $52.0 \%$ AGs 単剤の効果としては むしろ評価されるべきとい方よう。一方，尿路感 染症 6 例, 敗血症 4 例に対しては, いずれも全例 著効ないし有効の優れた成績であった，起炎菌が 検出された42例の細菌学的効果は $62.5 \%$ の菌消失 率が得られ，筋注での $63.9 \%$ と注涪同等の結果 であった。

泌尿器科領域においては, 101例に本剂が投与さ れ，98例が主治医判定の可能な症例であった。 た，そのうちの96例が複雑性尿路感染症例で，91 例が UTI 薬効評価基準合致症例であった.91例の 患者背景をみると男性が $83.5 \%$ と多かった。 60 歳 以上の高齢者が全体の $81.3 \%$ ，カテーテル留置例 が $45.1 \%$ 占めて抒り，難治症例が多く含まれて いた，投与方法は本剂 $200 \mathrm{mg}$ 皇 2 回， 100 250ml の生理食塩液, 糖液, 電解質液などに 溶解し，1時間かけて点滴静注した例が多かった が，0.5時間，2 時間かけて点滴静注した症例がそ れぞれ 9 例及られた。投与日数は 5 日間が注とん ぞ（95.6\%）を占めた。臨床成績は，UTI 薬効評 価基準による判定では著効16例，有効34例，無効 41例で総合有効率は $54.9 \%$ で，筋注での $57.0 \%$ (159/279) とほ注同等の結果であった。UTI 群別 では 4 群（10例）の有効率が $90.0 \%$ と優れた成績 であったが， 5 群（8 例）では37.5\%にとどまっ た。従来の AGs 剂の筇注・点滴静注 ${ }^{12) 13) 14)}$, HAPA-B の筋注 ${ }^{2)}$ での群別の成績でも同様の傾 向がみられている.一方, 分離菌別には臨床効果, 
Table 28 Clinical efficacy of HAPA-B classified by infusion time (Doctor's evaluation of HAPA-B in internal and urological fields)

\begin{tabular}{|c|c|c|c|c|c|c|}
\hline \multirow{2}{*}{$\begin{array}{l}\text { Time } \\
(\mathrm{hr})\end{array}$} & \multirow{2}{*}{ No. of cases } & \multicolumn{4}{|c|}{ Clinical effects } & \multirow{2}{*}{ Efficacy rate $(\%)^{*}$} \\
\hline & & Excellent & Good & Fair & Poor & \\
\hline 0.5 & 10 & 3 & 4 & 3 & & 70.0 \\
\hline 1.0 & 147 & 28 & 71 & 21 & 27 & 67.3 \\
\hline 1.5 & 3 & 1 & 2 & & & 100 \\
\hline 2.0 & 12 & 2 & 5 & & 5 & 58.3 \\
\hline Total & 172 & 34 & 82 & 24 & 32 & 67.4 \\
\hline
\end{tabular}

細菌学的効果に㧧いてグラム陽性菌に比べグラム 陰性菌に対してやや良好の成績であった，とくに 症例全体の $27.5 \%$ 占め, 最も分離頻度の高かっ た P. aeruginosa に対しては，分離菌別臨床効果 で56.0\%の有効率，細菌学的効果で $65.6 \%$ の消失 率で，とくに良好な成績であった。

98症例に対する主治医判定では著効21例，有効 39例，やや有効15例，無効23例，有効率は61.2\% で, UTI 薬効評価基準による判定よりやや優れた 成績であった。

内科領域, 泌尿器科領域全体での主治医判定に よる点滴時間別臨床効果（Table 28）をみると， 0.5 時間，1時間の有効率は，それぞれ $70.0 \%$, $67.3 \%$ とほぼ同等であったが，2 時間の有効率は $58.3 \%$ とやや劣る結果であり, この傾向は泌尿器 科領域に怙ける点滴時間別臨床効果の成績でも同 様であった。今回の体液内濃度の測定において， 0.5 時間, 1 時間点滴時の血中濃度はピーク值の平 均濃度がそれぞれ $14.57 \pm 1.54 \mu \mathrm{g} / \mathrm{ml}, 14.13 \pm 4.44$ $\mu \mathrm{g} / \mathrm{ml}$ で, 前者がやや高值をとったものの, 類似 の血中濃度推移を示した。このことより，点滴時 間別臨床効果に扔いて 0.5 時間, 1 時間点滴の有効 率が同等であったのは妥当と考兄られた。

副作用については内科領域81例, 泌尿器科領域 101例の計182例について検討したが，何らかの 自・他覚的副作用の認められた症例は 3 例 $(1.6 \%)$ で，その内訳は食欲不振 1 例, 発熱 1 例, 皮疹 1 例であった。とくに, AGs 剤使用の際に最も危惧 される腎毒性, 耳毒性, 神経-筋伝達抑制作用の増 強による呼吸抑制作用などに関する異常反応は認
められなかった。臨床検査値の異常については肝 機能異常 7 例, 顕微鏡的血尿の軽度増加 1 例, 血 清 $\mathrm{K}^{+}$の軽度低下 1 例の計 9 例であった。これら の副作用, 臨床検查値異常はいずれも軽度で, 泀 とんぞが投薬中止, 治療終了後速やかに回復した. また，4 例の患者に本剂投与前後にオージオグラ ム，38症例の患者に対して音叉・ストップウオッ チ・医師の問診による聴力検查を施行したが，全 例に異常変動は認められなかった。

今回, 内科領域に打いては 1 回 $200 \mathrm{mg}, 1$ 日 3 回 投与例が 2 例 ( 8 日, 10 日間投与), 1 回 $200 \mathrm{mg}$, 1 日 2 回，20日間以上の長期投与例が 3 例（29日 間 2 例，35日間 1 例）経験されたが，本剤に基づ く自・他覚症状や臨床検査值などの異常反応は認 められなかった。

また，Ccrの低下した患者 (Ccr 30.6〜 50.7ml/ min.）が 5 例含まれていたが，同様に本剂に基づ く自・他覚症状や臨床検査值などの異常反応はみ られなかった。

一方, 本剂の筋注での副作用の発現例は749例中 7 例 $(0.9 \%)$ で，その内容は皮疹・発疹が 3 例, 足先端のしびれ 1 例, 脱力感・耳鳴増強 1 例, 食 欲不振 1 例, 下痢 1 例であった ${ }^{2)}$. また, 臨床検查 值異常の発現例は749例中59例で, その内容は肝機 能，腎機能，血管障害等で重篤なものはみられな かった2).

副作用, 臨床検査值の今回の検討結果から, HAPA-B 点滴静注に颃いても筋注時と同様に安 全性は高いものと推察された。

以上より, 本剤の0.5 1 時間の点滴静注投与は 
有効性・安全性で筋注投与とほぼ同等の成績であ

り，臨床上有用な投与方法になるものと考えられ た。

\section{文献}

1) Nagabhushan, T.L., Cooper, A.B., Tsai, H., Daniels, P.J.L. \& Miller, G.H.: The syntheses and biological properties of 1-N-(S-4-amino-2hydroxybutyryl) gentamicin B and 1-N-(S-3amino-2-hydroxypropionyl) gentamicin B. J. Antibiotics, 31: 681-687, 1978.

2) 第31回日本化学療法学会東日本支部総会. 新薬シ ンポジゥム, HAPA-B, 1984.

3) Jones, R.N., Barry, A.L.. Fuchs, P.C., Gavan, T. L., Gerlach, E.H., Sommers, H. \& Thornsberry, C. : 1-N-(S-3-amino-2-hydroxypropionyl) gentamicin B (Sch 21420): A collaborative in vitro susceptibility comparison with amikacin and gentamicin against 12984 clinical bacterial isolates. Curr. Microbiol., 1: 359-364, 1978.

4）上田 泰編：アミノ配糖体薬。吸収・分布・代謝・ 排泄一清水喜八郎， $147-155$, 南江堂, 1985 。

5）鈴木恵三：アミノ配糖体系抗菌剂の点滴投与法に 扣ける利点と課題。医薬ジャーナル，19:523 $-527,1983$.

6) 中島光好, 金丸光隆：HAPA-B の点滴静注投与 による臨床第一相試験。未発表。
7）大越正秋, 河村信夫 (UTI 研究会代表)：UTI 薬 効評価基準 (第二版). Chemotherapy, 28：324 $-341,1980$.

8）谷本普一, 立花昭生, 鈴木幹三, 中田紘一郎, 岡 野 弘, 滝沢正子: 緑膿菌呼吸器感染症に打忛る Amikacin 点滴静注療法の検討. Chemotherapy, $29: 132-139,1981$

9）村橋 勲, 豊田晶雄, 高崎悦司：泌永器科領域に 括ける Amikacin 点滴静注の経験. J.J.A., $34: 133$ -139, 1981.

10) Barza, M. \& Scheife, R.T.: Drug therapy views : Antimicrobial spectrum, pharmacology and therapeutic use of antibiotics-part 4: Aminoglycoside. Am. J. Hosp. Pharm., 34 : 723 $-737,1977$.

11）本田一陽, 滝島 任：HAPA-B に関する臨床的・ 細菌学的検討. Chemotherapy, 33：141-148, 1985.

12）第28回日本化学療法学会総会：新薬シンポジゥ 厶, KW-1070, 1980.

13）第31回日本化学療法学会総会：新薬シンポジゥ ム, HBK, 1983.

14）河村信夫：ミクロノマイシン静注研究会（代表： 大越正秋・真下啓明・中川圭一) Micronomicin 点 滴静注の臨床的検討, 尿路感染症について. J.J.A., $37: 122-135,1984$. 
Fundamental and Clinical Studies on Intravenous Drip Infusion of HAPA-B Intravenous Drip Infusion HAPA-B Research Group

Masataka KATSU

National Kasumigaura Hospital Atsushi SAITO

The Second Department of Internal Medicine, The Jikei University School of Medicine Shigeki ODAGIRI

Department of The Chest, Kanagawa Prefectural Nagahama Hospital Hiroichi KISHI

Department of Urology, Faculty of Medicine, University of Tokyo Akira SAITO

College of Medical Technology, Hokkaido University Ichiro NAKAYAMA

Department of Internal Medicine, Sapporo Tetsudo Hospital Kazuo TAKEBE

The Third Internal Medicine, Hirosaki University, School of Medicine

Toyokazu TAMURA, Katsumi ENDO, Masashi YONEDA \& Yasuo IDO

Department of Internal Medicine, Hokusyu Central Hospital

Minoru SATOH, Hajime YAMAGATA \& Shinji OKUI

Department of Internal Medicine, National Kasumigaura Hospital

Akio AOYAGI

Department of Internal Medicine, National Higashi-Saitama Hospital

Mitsuo KITAHARA \& Yukinori TAKAHASHI

Department of Internal Medicine, Saiseikai Central Hospital

Keisuke TOYAMA \& Masahiro KIZAKI

Department of Internal Medicine, School of Medicine, Keio University Kihachiro SHIMIZU

Department of Internal Medicine, Tokyo Women's Medical College

Hiroyuki KOBAYASHI, Hiroshi OSHITANI \& Masahiko YOSHIDA

The First Department of Internal Medicine, Kyorin University, School of Medicine Yasushi UEDA

The Jikei University School of Medicine

Takashi INAMATSU

Infectious Disease Section, Tokyo Metropolitan Geriatric Hospital

Yuzo FUNATSU \& Fuyuhiko HIGASHI

Department of Internal Medicine, Tokyo Denryoku Hospital

Yoshio KOBAYASHI \& Ippei FUJIMORI

Department of Internal Medicine, Kawasaki Municipal Hospital

Fumio MATSUMOTO

Department of Internal Medicine, Kanagawa Prefectural Nursing and Hygienic School Hospital Masanori MATSUMURA, Kaneo SUZUKI, Koou MUROHASHI, Hisako SUZUKI, Yasuhiro YOSHIIKE, Mitsuyo KIUCHI \& Tsutomu FUKUDA

Department of The Chest, Kanagawa Prefectural Nagahama Hospital Kaoru OYAMA

Department of Internal Medicine, Toyama Prefectural Hospital Yuruko OKAMOTO, Seibun YONEZU \& Kojiro YASUNAGA The First Department of Internal Medicine, Kansai Medical University 
Yoshihiro UEDA \& Hiroshi OKUBO

Department of Internal Medicine, Rakusai New Town Hospital, Kansai Medical University

Masayoshi SAWAKI, Keiichi MIKASA \& Riichiro MIKAMI

Department of Internal Medicine, The Second Department of Internal Medicine, Nara Medical University

Rinzo SOEJIMA, Hiroshi KAWANE, Yoshihito NIKI, Michifumi ADACHI,

Toshio KISHIMOTO \& Masaru SUMI

Division of Respiratory Diseases Department of Medicine, Kawasaki Medical School

Yoshiro SAWAE, Kaoru OKADA \& Yukio KUMAGAI

The First Department of Internal Medicine, Faculty of Medicine and School of Health Sciences, Kyushu University

Kohei HARA, Atsushi SAITO, Keizo YAMAGUCHI, Yoji SUZUYAMA

Yoshiteru SHIGENO \& Shigeru KOHNO

The Second Department of Internal Medicine, Nagasaki University, School of Medicine

Takakazu KIYA

Department of Internal Medicine, Ureshino National Hospital

Takeshi ISHIZAKI \& Yasumasa DOHTSU

Department of Internal Medicine, Goto Chuo Hospital

Keizo MATSUMOTO, Toshiaki YOSHIDA \& Kazunori OISHI

Department of Internal Medicine, Institute of Tropical Medicine, Nagasaki University

Noriaki TANAKA, Katsuyuki MITOBE \& Yoshiaki KUMAMOTO

Department of Urology, Sapporo Medical College

(Director: Prof. Yoshiaki KUMAMOTO)

Isao MURAHASHI \& Etsuji TAKASAKI

Department of Urology, Dokkyo University School of Medicine

Takashi TOMINAGA \& Tadao NIIJIMA

Department of Urology, Faculty of Medicine, University of Tokyo

Isao SAITO

Department of Urology, Tokyo Kyosai Hospital

Yasunori ISHII

Department of Urology, Saitama Central Hospital Social Health Insurance

Toyohei MACHIDA, Shoichi ONODERA \& Hiroshi KIYOTA

Department of Urology, The Jikei University School of Medicine

Kenichi SAITO

Department of Urology, National Okura Hospital

Keizo SUZUKI \& Katsuo TAKANASHI

Department of Urology, Hiratsuka Municipal Hospital

Toshimi TAKEUCHI, Yoshito BAN \& Tsuneo NISHIURA

Department of Urology, Gifu University School of Medicine

Joji ISHIGAMI*, Akira FUJII \& Sadao KAMIDONO

Department of Urology, Kobe University, School of Medicine (*National Kobe Hospital)

Hideo OOSHIMA

Department of Urology, Hyogo Prefectural Kakogawa Hospital

Yasuharu NAKANO

Department of Urology, Akoh City Hospital

Hiroyuki OHMORI, Hiromi KUMON \& Yoshitsugu NASU

Department of Urology, Okayama University, Medical School

Atsushi KONDO \& Katsuyoshi KONDO

Department of Urology, Okayama Red Cross Hospital

Katsuichi NANBA

Department of Urology, Okayama City Hospital 


\author{
Tetsuzo KANESHIGE \\ Department of Urology, Okayama Central Hospital \\ Shinichi KAJI, Tetsuro MATSUMOTO \& Joichi KUMAZAWA \\ Department of Urology, Faculty of Medicine, Kyushu University
}

The clinical efficacy and safety of HAPA-B, a new aminoglycoside, was investigated fundamentally and clinically by intravenous drip infusion for internal (81 Cases) and urological (101 Cases) field infections. The following results were obtained.

1. After 1 hour infusion of $200 \mathrm{mg}$ of HAPA-B, the mean value of peak serum and plasma concentration was $14.13 \pm 4.44 \mu \mathrm{g} / \mathrm{ml}$ at the termination of infusion. In patients with impaired renal function, the plasma concentration of HAPA-B tended to be maintained higher and urinary recovery rates after $12 \mathrm{hrs}$ found decreased in parallel with the decreased value of creatinine clearance.

2. Clinical efficacy of HAPA-B on internal field infections were $70.5 \%(43 / 61)$ for respiratory tract infections, $100 \%$ (6/6) for urinary tract infections and $100 \%$ (7/7) for other infections, respectively, with a total effectiveness rate of $75.7 \%$. Its bacteriological efficacy was $62.5 \%$.

3. Clinical effectiveness rate of HAPA-B on urological field infections was $61.2 \%(60 / 98)$ by doctor's evaluation. According to the criteria of UTI committee, the effectiveness rate was $54.9 \%(50 / 91)$ and the bacteriological efficacy was $68.3 \%$.

4. Clinical symptoms seemed to be side effects were observed in three cases $(1.6 \%)$ of 182 cases and abnormal laboratory findings were observed in nine cases. But all of them were transient without severe reactions observed.

5. It was suggested from these investigations that intravenous drip infusion of HAPA-B was as effective and safe as intramuscular injection. Therefore, the intravenous drip infusion of HAPA-B will be useful for treatment of infections. 